Review

\title{
Single Cell Protein: A Potential Substitute in Human and Animal Nutrition
}

\author{
Bogdan Constantin Bratosin ${ }^{1}$, Sorina Darjan ${ }^{2}$ and Dan Cristian Vodnar $1,2, *$ (D) \\ 1 Department of Food Science, University of Agricultural Science and Veterinary Medicine, Calea Mănăstur \\ 3-5, 400372 Cluj-Napoca, Romania; bogdan-constantin.bratosin@usamvcluj.ro \\ 2 Institute of Life Sciences, University of Agricultural Science and Veterinary Medicine, Calea Mănăstur 3-5, \\ 400372 Cluj-Napoca, Romania; sorina.darjan@usamvcluj.ro \\ * Correspondence: dan.vodnar@usamvcluj.ro
}

check for updates

Citation: Bratosin, B.C.; Darjan, S.; Vodnar, D.C. Single Cell Protein: A Potential Substitute in Human and Animal Nutrition. Sustainability 2021, 13, 9284. https://doi.org/10.3390/ su13169284

Academic Editor:

Alessandra Durazzo

Received: 7 July 2021

Accepted: 14 August 2021

Published: 18 August 2021

Publisher's Note: MDPI stays neutral with regard to jurisdictional claims in published maps and institutional affiliations.

Copyright: (c) 2021 by the authors. Licensee MDPI, Basel, Switzerland. This article is an open access article distributed under the terms and conditions of the Creative Commons Attribution (CC BY) license (https:// creativecommons.org/licenses/by/ $4.0 /)$.

\begin{abstract}
Single cell protein (SCP) is the first product of the fermentation process and has proven to be a good protein alternative. Food competition is becoming more intense as the world's population continues to grow. Soon, SCP may be able to compensate for a protein deficit. Various global businesses are focusing on SCP production, and the scope of its application is expanding as time and knowledge increases. High quantities of SCP can be produced by microorganisms, such as algae, yeast, fungi and bacteria, due to their fast development rate and the significant level of protein in their chemical structure. Beside proteins, SCP contains carbohydrates, nucleic acids, lipids, minerals, vitamins and several important amino acids. SCP has been an effective substitute for more expensive protein sources such as fish and soybean products. In conclusion, SCP can easily replace traditional protein sources in human and animal feed without detrimental effects. Potential substrate candidates and optimization strategies for SCP production have been extensively studied. This review article focuses on the various aspects of SCP, from its production, using different substrates, player microorganisms and nutritional benefits, to its economic aspects.
\end{abstract}

Keywords: single cell protein; algae; yeast; fungi; bacteria; mechanism of production; nutritional benefits

\section{Introduction}

The world population is continuously increasing. By 2050, the world population could increase to 9.3 billion $[1,2]$ which at current consumption levels would cause the global demand for animal-derivative protein to reach 1250 million tons per year [3]. On the other hand, recent evidence has shown that almost 690 million people in the world (8.9 percent of the world population) are estimated to have been undernourished in 2019, and this is estimated to exceed 840 million by 2030. The most affected regions are Africa, Asia, Latin America and (to a lesser extent) the Caribbean [4]. Forecasting studies have shown that population increase will also be accompanied by economic progress, and consequently the increase in the living standard of about 3 billion people. It means that not only will water and food demands increase, but also the number of people who have more exigencies for food quality [5].

The United Nations Food and Agriculture Organization (FAO) describes proteins as macromolecules that make up the structural components of cells, tissues, muscles and organs. Proteins are required for metabolic function and are the nitrogen source for both humans and animals to build the structural and functional units required for living. The composition of a protein's constituent amino acids reveals its nutritional worth. The most frequent are necessary amino acids, which humans and animals cannot synthesize. As a result, we consume meat or a protein sources to meet these needs [6].

Single cell proteins (SCPs) are isolated from the cells of microorganisms with high protein content as dried cells and/or as purified proteins. SCPs show very attractive features as a nutrient supplement for humans as they have a high protein content with 
wide amino acid spectrum, low fat content and a higher protein:carbohydrate ratio than forages [7]. SCPs contain vitamins, e.g., thiamine, riboflavin, pyridoxine, nicotinic acid, pantothenic acid, folic acid, biotin, cyanocobalamin, ascorbic acid, $\beta$-carotene and $\alpha$ tocopherol; essential amino acids, represented by lysine and methionine; minerals; nucleic acids and lipids [8,9]. Until now, SCPs have been used for a wide range of purposes, from food (aroma carriers, vitamin carriers, emulsifying acids, etc.) and feed (pigs, poultry, cattle, fish) production, to the paper and lead industry $[9,10]$.

Common sources for SCPs are represented by waste and raw materials (starch, fruit, fruit waste, molasses, etc.), combustible and/or combustible waste and/or byproducts (natural gas, petroleum byproducts, ethanol, methanol, biomass, etc.) [8]. Methanol is soluble in its aqueous phase at all concentrations, and it can be easily removed from harvested biomass. Ethanol is a good substrate, but the process is not economically feasible. There are several advantages to utilizing waste for SCP production; these include the conversion of low-cost organic waste to useful products and a reduction in environment pollution. The cellulose, hemicellulose and lignin of natural waste wood originating from agriculture and forestry sources are attractive natural sources of SCP. However, they must be pretreated chemically (acid hydrolysis) or enzymatically (cellulases) to transform cellulose into fermentable sugars. Domestic sewage and waste retained from industrial cellulose processing, starch production and food processing can also be utilized. Agricultural waste has been reported to be an excellent substrate for cost-effective SCP production, the resulting protein-enriched product being of good quality and suitable for animal feed. It can even be consumed by humans after further processing [11].

The production of SCP from non-waste sources achieved industrial-scale production in the 1970s but was not economically competitive with other protein supplements Recently, interest in SCP has been renewed, partly because of the identification of new, less expensive production processes, but largely due to the realization that SCP production has vast potential environmental benefits over traditional protein supplements in animal feed [12].

\subsection{Historical Background of SCP}

Many microorganisms have been directly utilized as food. SCPs can be lifesaving in less privileged areas where malnutrition is a real and life-threatening problem. A species of alga called Spirulina was grown many years ago in Africa's Lake Chad, and was subsequently used as food to compensate for local people's protein shortfall [6]. Germans reportedly utilized a certain species of Candida in their meals during World War I, including sausages and soups. Proteins generated from bacterial, fungal and algal cultures were widely used in food and as food from then on. The concept of SCP arose from this method, and these proteins are now widely used [13].

\subsection{Applications of SCP}

SCP produced on commercial scale is used [13]:

- In animal feed and nutrition, for the stuffing and fattening of poultry, laying hens, calves and pigs.

- As food additives (vitamin and aroma carriers and emulsifying agents), to enhance nutritional value (of baked food items, ready-made meals, soups, etc.) and as starter cultures (baker's, brewer's and wine yeast).

- In industrial processes, as a foam-stabilizing agent and in paper and leather processing.

\subsection{Mechanism of Production}

There are different kinds of substrates, as categorized in [14]:

- High-energy resources: gas oil, natural gas, ethanol, methanol, $n$-alkanes and acetic acid

- Renewable plant resources: starch, sugar and cellulose

- Various wastes: sulfite waste liquor, molasses, whey, milk and fruit waste

- Carbon dioxide 
The choice of substrate is made according to cost, availability, oxygen required during fermentation, quantity of heat produced and cooling capacity of the fermenter, but also the cost related to post-treatment processing $[8,14]$. Selected substrates are used as a growth medium by microorganisms such as bacteria, algae, fungi and yeast for increasing their cell mass, which is made up of SCP [15]. Fermentation is the main process responsible for SCP production [16], as shown is Figure 1.

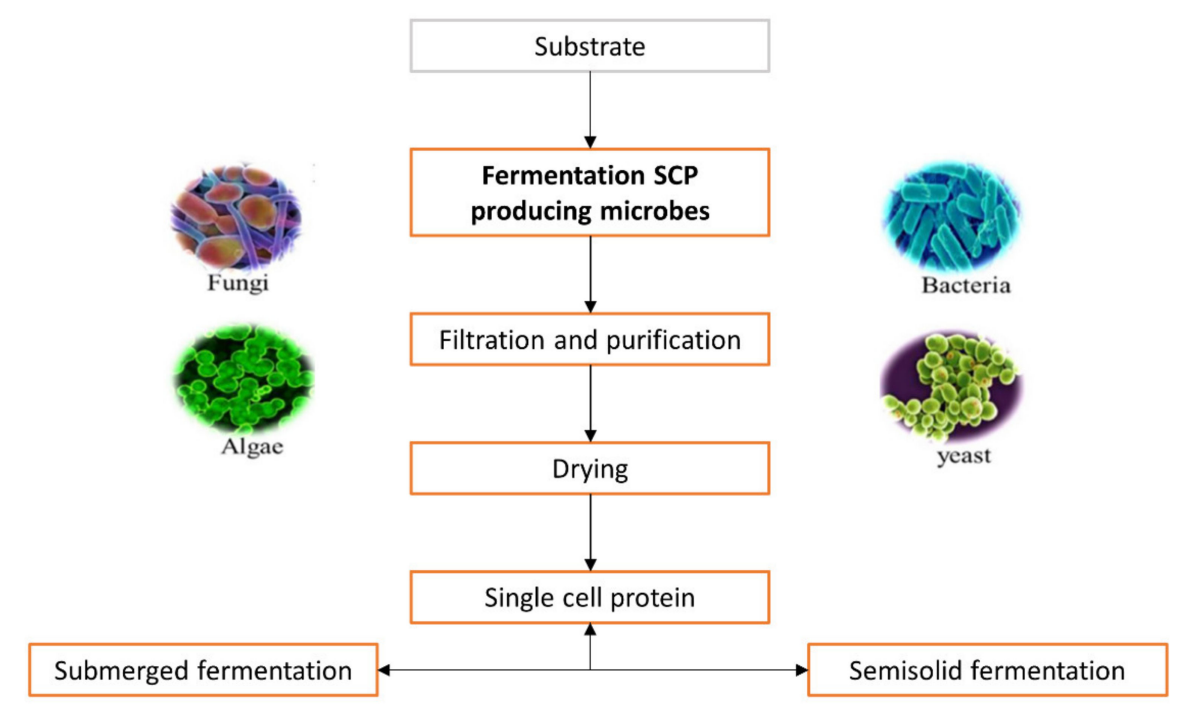

Figure 1. General steps during industrial production of single cell proteins.

The available biomass is harvested when the fermentation process is completed and can be used as a protein source [17]. The biomass is processed further by purification, cell disruption, washing and protein extraction [18] to provide high production rates with high yields.

The demand for protein is increasing due to changes in food consumption patterns. However, the reliance on animal and dairy production to meet the growing demand for protein is ultimately unsustainable [3]. Hence, alternative sources should be explored to supply food for humans and animals [19].

SCP is widely viewed as a potential co-product that could boost the economic potential of a biorefinery process that is otherwise unprofitable and lower the downstream processing costs associated with the disposal of process waste. It is preferable to sell residual biomass as feed rather than as fertilizer. This can be seen in numerous publications in which specific waste products are converted to SCP and are assessed as food for specific animals [3].

The current review focuses on the various aspects of SCP, i.e., its application and the selection of a substrate and production method using different microbial sources (microalgae, yeast, fungi and bacteria), and also aims to identify future perspectives and challenges related to SCP. Data summarized herein can support researchers to create a foodgrade SCP product with a high nutritional value (in terms of proteins, vitamins and lipids) by selecting the most suitable potential microorganism and a cost-effective technology.

\section{Bacterial Metabolism}

Bacteria have a wide range of metabolic processes characterized by enzymatic assimilation (the intake and use of organic and inorganic chemicals required for cellular growth and maintenance) and dissimilation reactions (the oxidation and breakdown of substrate). Assimilation reactions are endergonic, which means they require energy, whereas dissimilation reactions are exergonic, which means they generate energy. These reactions form the basis of the bacterial cell's self-replication and are involved in critical functions of the cell [20].

Vasdekis and Stephanopoulos (2015) describe bacteria as cells that can value the energy they capture from the environment to accomplish their essential operations, thanks to their 
particular energy-transforming ability [21]. Chemical energy is conserved in adenosine triphosphate (ATP), adenosine diphosphate (ADP) and/or molecules with a thioester link (e.g., succinyl SCoA and acetyl SCoA). These compounds have high energy phosphate bonds, which are used by enzymatic systems to synthesize new compounds needed for cell existence and development.

Bacterial enzymatic systems include B-complex vitamins as functional coenzymes that are involved in cell growth and energy transformation processes by catalyzing many oxidation-reduction reactions [22].

SCP metabolism involves the biological oxidation of organic compounds and yields simple organic and/or inorganic compounds together with ATP. The bacterial cell needs these compounds for anabolic pathways. Two modes of energy production are known in bacteria within heterotrophic metabolism: anaerobic respiration or fermentation (Figure 2A) and aerobic respiration (Figure 2B). Energy production may occur in both aerobic and anaerobic environments.

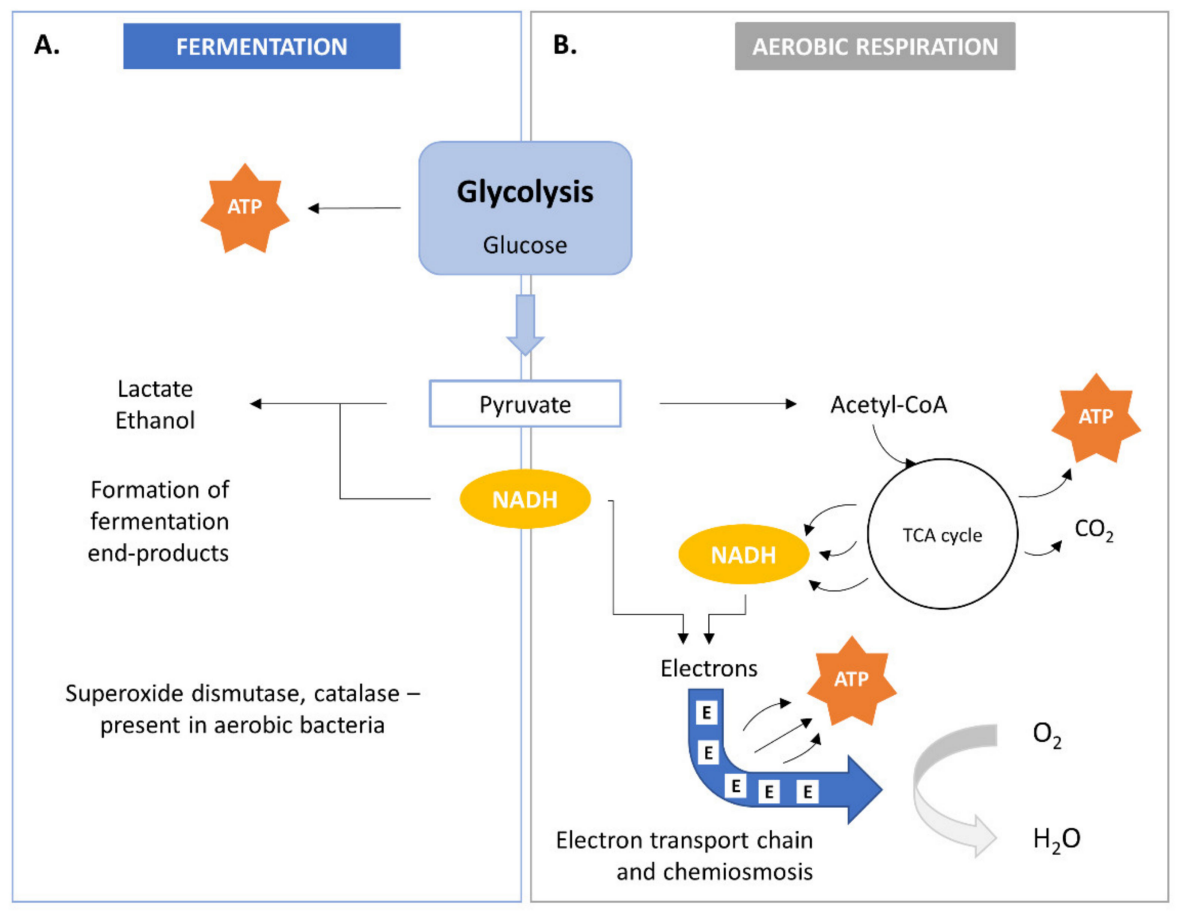

Figure 2. Bacterial metabolism by fermentation (A) and aerobic aspiration (B). TCA, tricarboxylic acid.

The fermentation is an anaerobic process, meaning that the terminal electron acceptor is other than $\mathrm{O}_{2}$ (e.g., $\mathrm{SO}_{4}{ }^{2}, \mathrm{NO}^{3-}$ or fumarate). Through glycolysis, glucose is broken down into pyruvate, yielding ATP and NADH (by the conversion of NAD). Pyruvate, in the presence of $\mathrm{NADH}$, yields the end products of fermentation (Figure 2A). Aerobic respiration involves glucose catabolism. The pyruvate resulting from glucose breakdown produces acetic acid, carbon dioxide and NADH through mechanisms involving electron transport and chemiosmosis. Acetic acid together with coenzyme A yields acetyl SCoA, then acetyl radical enters in reaction cycle (Krebs or Glyoxylate) by detaching from CoA. The aerobic respiration is an exothermic process, yielding 380,000 calories when 1 mole of glucose is broken down by complete oxidation into carbon dioxide and $\mathrm{H}_{2} \mathrm{O}$, generating about 38 moles of ATP (Figure 2B).

\section{Bacterial Sources}

Bacterial SCP contains $50-80 \%$ protein (dry weight) [23], and is characterized by rich nucleic acid content, low density, small cell size and the capacity to easily multiply (within an interval of 20-120 min) on a wide range of substrates, such as sugar, starches, raw 
materials, waste (i.e., organic waste and petrochemicals such as methanol and ethanol), and even water resources with a high nutrient and mineral content (Table 1) $[8,24,25]$. Plantbased products are mainly used as a substrate for SCP production. The most suitable waste for SCP production is agricultural waste, because when industrial waste is categorized it includes some of the agricultural waste that is generated by the food to be processed in industries [6]. Some bacteria (Methyloccus capsulatus, Methylomonas methanica, Methylovibrio soehngenii) can utilize methane for SCP production [26]. It can be observed from Table 1 that bacterial species like Methylophilus methylotrophus Rhodopseudomonas palustris, Escherichia coli and Haloarcula sp. are very efficient in SCP production, so they have been most often exploited as protein producers.

Table 1. Bacterial protein content as single cell protein (SCP) on specific substrates.

\begin{tabular}{|c|c|c|c|}
\hline Bacteria & Substrate & SCP $(\%)$ & Reference \\
\hline Afifella marina STW181 & Commercial shrimp feed & $>46$ & [27] \\
\hline Bacillus cereus & Ram horn & 68 & [28] \\
\hline Bacillus licheniformis & Potato starch processing waste & 38 & [29] \\
\hline Bacillus pumilis & Potato starch processing waste & 46 & [30] \\
\hline Bacillus subtilis & Ram horn & 71 & [28] \\
\hline Bacillus subtilis $s p$ & Soybean hull & 26 & [31] \\
\hline Corynebacterium ammoniagenes & Glucose + fructose & 61 & [32] \\
\hline Cupriavidus necator & Synthetic growth medium & $40-46$ & [33] \\
\hline Escherichia coli & Ram horn & 66 & [28] \\
\hline Haloarcula sp. IRU1 & Petrochemical wastewater & 76 & [34] \\
\hline $\begin{array}{c}\text { Methylococcus capsulatus, Ralstonia } \\
\text { sp., Brevibacillus agri, } \\
\text { Aneurinibacillus sp. }\end{array}$ & Methane (natural gas) & $67-73$ & [25] \\
\hline $\begin{array}{l}\text { Methylomonas and Methylophilus } \\
\text { spp. Metilococ capsulatus }\end{array}$ & $\begin{array}{l}\text { Gas and liquid products of } \\
\text { sewage }\end{array}$ & $<41$ & [19] \\
\hline Methylophilus methylotrophus & Methanol & 81 & {$[25]$} \\
\hline Methylococcus capsulatus (bath) & Methane & 53 & [35] \\
\hline Methylophilus methylotrophus & Methanol & $<70$ & [3] \\
\hline Methylophilus $s p$ & Supernatant and biogas & 24 & [19] \\
\hline Methylocapsa acidiphila & Methane & 59 & [36] \\
\hline Methilomonas.sp & Natural gas & 69.3 & {$[37]$} \\
\hline Methilomonas.sp & $\begin{array}{l}\text { Biogas and supernatant of sewage } \\
\text { sludge }\end{array}$ & 56 & [19] \\
\hline $\begin{array}{l}\text { Rhizospheric diazotrophs (whole } \\
\text { microbial community }\end{array}$ & Brewery wastewater & $>55$ & [38] \\
\hline Rhodopseudomonas blastica & Wastewater from a latex rubber & 66.7 & [39] \\
\hline Rhodopseudomonas palustris & Sludge and sago starch processing & $72-74$ & [40] \\
\hline Rhodocyclus gelatinosus & $\begin{array}{c}\text { Poultry slaughterhouse } \\
\text { wastewater }\end{array}$ & 67.6 & [41] \\
\hline Rhodobacter sphaeroides P47 & Pineapple waste & 66.6 & [42] \\
\hline Rhodopseudomon as palustris P1 & Fermented pineapple extract & 65 & [39] \\
\hline Rhodobacter sphaeroides Z08 & Soyabean wastewater & 52 & [43] \\
\hline Rhodovulvum sulphidophilum & Glutamate malate medium & 15,6 & [44] \\
\hline Rhodocyclus gelatinosus & Pig farm waste & 50.6 & [45] \\
\hline Rhodopseudomonas and R. fulvum & Sugar refinery wastewater & 58 & [46] \\
\hline Rhodocyclus gelatinosus & Miso-like effluent medium & 63 & [47] \\
\hline Rhodobacter sphaeroides P47 & $\begin{array}{l}\text { Dehydrated medium from } \\
\text { pineapple peel waste }\end{array}$ & 66.6 & [42] \\
\hline Rhodocyclus gelatinosus & Seafood processing wastewater & 50 & [48] \\
\hline Rhodopseudomonas sp. & Synthetic medium & 11 & [49] \\
\hline $\begin{array}{l}\text { Rhodopseudomonas palustris } \\
\text { Rhodopseudomonas sp. }\end{array}$ & $\begin{array}{l}\text { Wastewater from noodle } \\
\text { production }\end{array}$ & 50 & [50] \\
\hline Rhodopseudomonas sp. CSK01 & Municipal wastewater & 60.1 & [51] \\
\hline Rhodocyclusg elatinosus R7 & Tuna condensate & 56 & {$[52]$} \\
\hline Rhodobacter capsulatus & Synthetic medium & 45 & [53] \\
\hline Rhodopseudomonas acidophila & Synthetic medium & 23 & [54] \\
\hline Rhodocyclus gelatinosus & Cassava waste & 56 & [55] \\
\hline Rhodopseudomonas palustris & Simulated wastewater & 45 & [56] \\
\hline Rhodopseudomonas palustris & Photosynthetic sludge & 74 & [57] \\
\hline
\end{tabular}


To be considered suitable for SCP production, bacterial strains must accomplish the requirements stipulated by several criteria: reaction conditions (heat and oxygen requirements during fermentation and foam generation); performance (yield, growth rate, $\mathrm{pH}$ and heat tolerance); behavior during fermentation (growth morphology and genetic stability); end product (in terms of bacterial protein composition and structure, purification yield and recovery rate) [58].

In a study by Kurbanoglu and Algur (2002), ram horn hydrolysate was processed in a batch system at 30 degrees Celsius in the presence of Bacillus cereus NRRL B-3711, Bacillus subtilis NRRL NRS-744 and Escherichia coli. The obtained bacterial cells had high total protein content $(66 \%, 68 \%$ and $71 \%$ for Escherichia coli, Bacillus cereus and Bacillus subtilis, respectively). The obtained protein contained all amino acids for ruminant feed (alanine aspartic acid, cystine glutamic acid, glycine, serine, tyrosine, arginine, histidine, isoleucine, leucine, lysine, methionine, phenylalanine, proline, threonine, tryptophan and valine) [28]. Øverland et al. (2010) demonstrated that a bacterial culture (Methylococcus capsulatus, Ralstonia sp., Brevibacillus agri, Aneurinibacillus sp.) grown on natural gas as a carbon source and containing mainly the methanotroph Methylococcus capsulatus is a promising source of protein (67-73\%) [25]. Imperial Chemical Industries developed a SCP (Pruteen) for animal feed from methanol using the bacterium Methylophilus methylotrophus. Pruteen contained up to $70 \%$ protein and is used in pig feed [59]. Photosynthetic purple nonsulfur bacteria (PPNSB) (Rhodopseudomonas sp, Rhodobacter sp, Rhodocyclus sp) cultivated on industrial wastewater containing heavy metals $\left(\mathrm{Hg}^{2+}, \mathrm{Cr}^{6+}, \mathrm{Pb}^{2+}\right)$ produced $70-72 \%$ crude protein. The strain proved to have efficient tolerance to those ions $[60,61]$. The amino acid profile of the protein composition (arginine, aspartic acid, cystine, glutamic acid, glycine, histidine, isoleucine, leucine, lysine, methionine, phenylalanine, proline, serine, threonine, tryptophan, tyrosine, valine) was similar to soybean protein (aspartic acid, glutamic acid, leucine, arginine, isoleucine, lysine, methionine, phenylalanine, proline, serine, threonine, tryptophan, tyrosine, valine) [23,62]

Kantachote et al. (2005) reported a protein percentage of $66.7 \%$ in fermented latexrubber-sheet wastewater using bacteria Rhodopseudomonas blastica [63]. About 72-74\% SCP was obtained by Getha et al. (1998) from sludge and sago starch processing with Rhodopseudomonas palustris [40]. The bacterial biomass was used as aquaculture feed. Ponsano et al. (2003) observed $67.6 \%$ SCP from Rhodocyclus gelatinosus culture in poultry slaughterhouse wastewater. The bacterial biomass was used as a feed supplement [41]. Noparatnaraporn and Nagai (1986) used Rhodobacter sphaeroides P47 cultured in pineapple waste and reported $6.6 \%$ SCP [42]. Rhodopseudomonas palustris cultured in fermented pineapple extract contained 65\% SCP and was used for the treatment of latex rubber sheet wastewater [39]. Rhodobacter sphaeroides Z08 produced 52\% SCP when used soybean wastewater as a substrate [43]. Rhodovulvum sulphidophilum grown in glutamate malate medium produced 15.6\% SCP [44]. Rhodocyclus gelatinosus produced 50,6\% SCP from pig farm waste [45]. Rhodopseudomonas and Rhodopseudomonas fulvum produced 58\% SCP from sugar refinery wastewater [23]. 63\% SCP was produced from Rhodocyclus gelatinosus on miso-like effluent medium [47]. Rhodobacter sphaeroides $P 47$ grown in dehydrated medium from pineapple peel waste produced $66.6 \%$ SCP [42]. Rhodocyclus gelatinosus produced 50\% SCP from seafood processing wastewater [48]. Rhodopseudomonas sp. grown in synthetic medium produced $11 \%$ SCP [49]. Rhodopseudomonas palustris and Rhodobacter blasticus grown in wastewater from noodle production produced 50\% SCP [50]. Saejung and Thammaratana (2016) reported $60.1 \%$ SCP production from culturing Rhodopseudomonas sp. CSK01 cultured from municipal wastewater [51]. Rhodocyclus gelatinosus $R 7$ produced $56 \% \mathrm{SCP}$ from tuna condensate [52]. Alexandre AJ et al. (2009) reported 45\% SCP from Rhodobacter capsulatus cultivated from a synthetic medium [53]. Rhodopseudomonas acidophila produced $23 \% \mathrm{SCP}$ from a synthetic medium (ammonium sulfate and sodium acetate) [54]. Noparatnaraporn et al. (1987) reported 56\% SCP from Rhodocyclus gelatinosus cultivated in cassava waste [55]. Rhodopseudomonas palustris grown in simulated wastewater produced $45 \%$ SCP [56]. Rhodopseudomona spalustris produced $74 \%$ SCP from photosynthetic sludge and 
the bacterial biomass was used as fish feed [57]. Methylocapsa acidiphila produced 59\% protein when methane was used as a substrate [36].Methanotrophic bacteria (Methylomonas spp. and Methylophilus spp.) produced $41 \%$ more protein content when sewage sludge was used as substrate. They also contain essential amino acids as histidine, valine, phenylalanine, isoleucine, leucine, threonine and lysine [19]. Methylomonas, widely used for SCP production [64], reached $69 \%$ protein when fed with natural gas. These were the growth conditions when methane salt broth and sodium nitrate were used as medium and nitrogen source, respectively [37]. Rhodobacter sphaeroides SS15 and A. marina STW181 (purple non-sulfur bacteria) mixed with commercial shrimp feed as a carbon source were explored by Chumpol Supaporn et al. (2018) [27]. Based on their protein content (53\% and $46 \%$, respectively) and essential amino acids, these biomasses are optimal for SCP. Bacillus licheniformis used waste potato as substrate to produce SCP. A temperature of $32.8^{\circ} \mathrm{C}$ and $\mathrm{pH}$ of 6.67 were the optimal fermentation conditions, and the concentration of inoculum was $1.78 \%$. These results demonstrate a potential application of this method in large-scale industrial production with $30 \%$ protein concentration [29].

SCP production was also reported by Kornochalert et al. (2014). Latex rubber sheet wastewater with added fermented pineapple extract was efficiently treated under microaerobic light conditions using Rhodopseudomonas palustris. The biomass contained $65 \%$ protein, $3 \%$ fat, $8 \%$ carbohydrate, $14 \%$ ash and $10 \%$ moisture. The SCP contained a higher content of protein, methionine and threonine concentration than soyabean meal (with $37 \%$ protein content) [39]. Kunasundari et al. (2013) cultivated Cupriavidus necator to produce a biomass high in both protein (40-46\%) and polyhydroxyalkanoate (serving as a source of energy and as a carbon store). This biomass was used to feed rats [33]. Taran and Asadi (2014) showed that Haloarcula sp. IRU1 degrade petrochemical wastewater and use it as carbon source for single cell protein production in different conditions. They obtained SCP with $76.4 \%$ protein content [34]. Soya bean hull obtained from soya bean oil extraction is a cheap feed ingredient with a high fiber content. Two strains of Bacillus subtilis MR10 and TK8 were isolated from tua-nao, a traditional fermented soya bean in northern Thailand. The protein content after fermentation was $25,6 \%$ for MR10 and 26,6 for TK8 [31].

In terms of its high protein content and based on recent bacterial SCP research, it can be concluded that Bacillus subtilis (71\%) together with Rhodopseudomonas palustris $(72 \%$ $74 \%$ ) and Rhodopseudomona spalustris (74\%) are the most exploited as protein producers, offering the advantage of high production rates and providing lipids and vitamins from the B group. However, bacterial SCP is disadvantaged by low familiarity and high nucleic acid content, which adds to the processing costs.

\section{Algal Metabolism}

The micro-algal metabolism refers to processes that include both biochemical mechanisms and nutrient transport. Intake nutrients are converted through a metabolic pathway into nutritional principles needed for vital processes, such as growth, reproduction and defense mechanisms. The mechanisms for the acquisition of carbon supplies, light capture, assimilation of nutrients (nitrogen and sulfur) and synthesis of the unique secondary metabolites make the difference between micro-algal metabolism and the metabolisms of other organisms [65].

The micro-algae display oxygen-evolving photosynthesis, which is a key feature that distinguishes them from other lower eukaryotes. This metabolic process is characterized by specific reactions often produced in the presence of light, at thylakoid membrane level. In algae, the basic chemo-organotrophic metabolism is similar to that encountered in bacteria. In algae, anabolic processes may occur both in the presence of light (photolithotrophic) or in the dark. The photorespiration process is catalyzed by specific enzymatic systems, including ATP syntheses, the cytochrome b6- $\mathrm{f}$ complex or enzymes specific to the photosynthetic carbon-reduction cycle. In micro-algae, the photosynthetic reactions yield carbohydrates as phosphates. The algae photolithotrophic metabolism involves pathways that cannot take place in the dark. There are known linear pathways that produce the synthesis of 
essential C skeletons, and they use photons, nitrogen, ammonium nitrate, ammonium sulfate, ammonium di-hydrogen phosphate and carbon dioxide for growth. Micro-algae that grow in the dark have only organic carbon as a source [66].

Figure 3 outlines the pathways of energy, carbon and oxygen in photosynthesis, photorespiration, dark respiration and the growth of an alga. No attempt is made to represent stoichiometries.

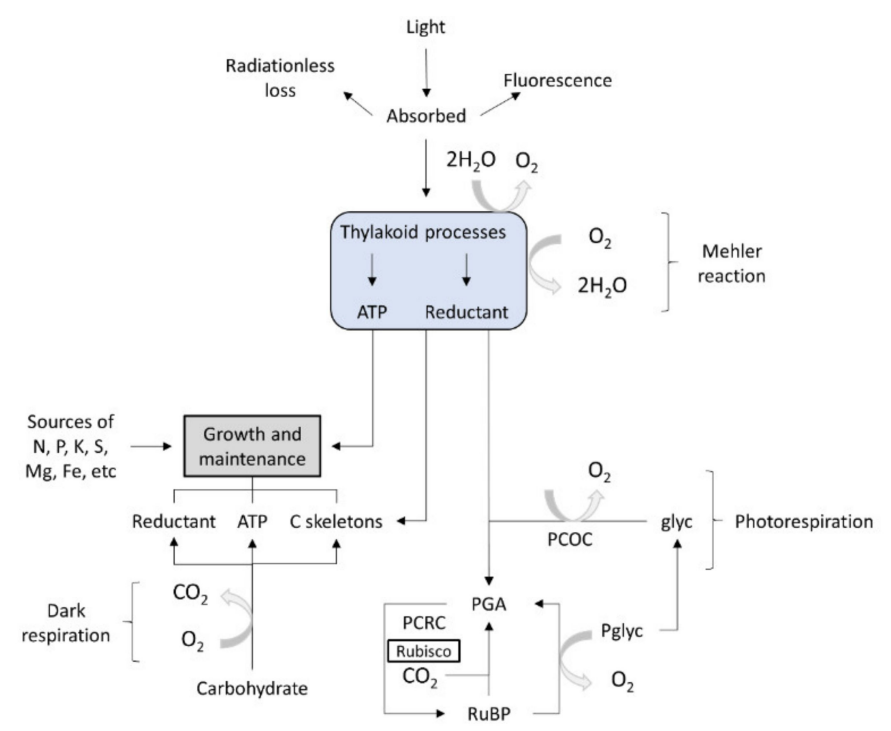

Figure 3. Algal metabolism [65]. Glyc, glycolate; PCOC, photorespiratory carbon-fixation cycle (or its equivalent); PCRC, photosynthetic carbon reduction cycle; PGA, 3-phosphoglycerate; Pglyc, phosphoglycolate; RuBP, ribulose bisphosphate; Rubisco, ribulose bisphosphate carboxylase-oxygenase.).

Algae Sources

Algae are autotrophic organisms characterized by wide genetic diversity. To sustain growth, besides inorganic nutrients (mainly nitrogen and phosphorus), they need water, carbon dioxide and light [67]. Environmental parameters such as $\mathrm{pH}$ and temperature also make influential contributions [68]. There are two algae categories: macro-algae (multicellular organisms) and micro-algae (unicellular organisms), commonly named phytoplankton and seaweed, respectively [69]. The macro-algae belong to four classes (phyla): i. cyanophyta (also known as the cyanobacteria group), are representative of the bluegreen algae responsible for water blooms (e.g., Spirulina, Anabaena, Nostoc), ii. chlorophyta (green algae, i.e., Ulva, Enteromorpha), iii. haptophyta (brown algae, i.e., Fucus, Laminaria, Ascophyllum, Macrocystis) and iv. rhodophyta/phodophyceae (red algae, the most diverse family, i.e., Porphyra, Rhodymenia) $[67,68]$. There is an enormous biodiversity of micro-algae species, with a high occurrence in marine systems, falling into five classes (phyla): i. chlorophyta (green micro-algae, i.e., Chlorella, Micractinium, Dunaliella, Scenedesmus in freshwater systems, Chaetomorpha antennina, Phaeodactylum, Micractinium, Skeletonema, Ulva fasciata in marine systems), ii. rhodophyta/phodophyceae (red micro-algae, i.e., Rhodella reticulata, Porphyridium cruentum in freshwater systems, Garcilaria, Laurencia Palmaria palmata and Porphyra umbilicalis in seawater systems), iii. haptophyta (brown algae, i.e., Pavlova salina in marine systems), iv. stramenopiles (including brown micro-algae, Skeletonema costatum, Chaetoceros muelleri, Thalassiosira pseudonana in marine systems) and v. dinophyta (i.e., Crypthecodinium cohnii in marine systems) [70].

The micro-algae have the capacity to produce cellular biomass with a major proportion of SCP (up to 70\%), by converting solar energy [71]. Micro-algae mass cultivation produces high yields, 20- to 50-fold higher than soybean yields [72]. Micro-algae are single cell microorganisms, characterized by autotrophic growth, using light and carbon dioxide as energy and carbon suppliers. Heterotrophic growth is characterized by the use of molasses, manure or other cheap organic materials (e.g., industrial waste) as a carbon 
source [73]. Some microalgae grow by combining both nutritional modes and are called mixotrophic algae.

Table 2. SCP production by algal species from different substrates.

\begin{tabular}{|c|c|c|c|}
\hline Algae & Substrate & $\mathrm{SCP}(\%)$ & Reference \\
\hline Chaetomorpha antennina & Soda ash effluent & $14.0-18.2 \%$ & [74] \\
\hline Ulva fasciata & Soda ash effluent & $13.7-18.6 \%$ & [74] \\
\hline \multirow[t]{3}{*}{ Chlorella sp. } & Tofu waste & $52.32 \% \pm 3.31$ & [75] \\
\hline & Tempeh waste & $52.00 \% \pm 1.80$ & [75] \\
\hline & Cheese waste & $15.43 \% \pm 2.55$ & [75] \\
\hline Chlorella salina & Saline sewage effluents & $51 \%$ & [76] \\
\hline Gracilaria domingensis & Natural habit & $6.2 \%$ & [77] \\
\hline Gracilaria birdiae & Natural habit & $7.1 \%$ & [77] \\
\hline Laurencia filiformis & Natural habit & $18.3 \%$ & [77] \\
\hline Laurencia intricate & Natural habit & $4.6 \%$ & [77] \\
\hline \multirow[t]{5}{*}{ Palmaria palmate } & Natural habit & $8-35 \%$ & [78] \\
\hline & Natural habit & $8.0-35.0 \%$ & [79] \\
\hline & Natural habit & $11.9-21.9 \%$ & [80] \\
\hline & Natural habit & $13.5 \%$ & [77] \\
\hline & Natural habit & $12-21 \%$ & [81] \\
\hline Chondrus crispus & Natural habit & $20.1 \%$ & [82] \\
\hline Porphyra umbilicalis & Natural habit & $15-37 \%$ & [81] \\
\hline Gracilaria verrucosa & Natural habit & $7.0-23.0 \%$ & [79] \\
\hline Chlorella sorokiniana & Wastewater & $45 \%$ & [35] \\
\hline Scenedesmus obliquus & Wastewater & $52 \%$ & [83] \\
\hline \multirow[t]{2}{*}{ Spirulina } & Salinated water & $48.59 \%$ & [84] \\
\hline & Desalinated wastewater & $56.17 \%$ & [84] \\
\hline
\end{tabular}

As shown in Table 2, several raw compounds are known as cultivation media and are used in micro-algae SCP production. For Chlorella, the literature mentions tempeh waste, with $52 \%$; tofu waste, with $52.32 \%$ and cheese waste, with $15.43 \%$ total protein content [75]. Wastewater has been reported as a growing medium for Scenedesmus obliquus green alga with yields of $52 \%$ protein content [83], for Arthrospira (Spirulina) platensis cyanobacterium with SCP yields $48.59 \%$ or $56.17 \%$ by dry weigh, depending on the culture medium [84]. Jadeja and Tewari (2008) obtained 10-35\% SCP yields using polluted water (soda ash industry effluent) as a carbon source for Ulva fasciata and Chaetomorpha antennina [74]. Different amounts of SCP were found in four red marine benthic species of algae collected from Espírito Santo State, Brazil: 18.3\% dry weight in Gracilaria birdiae, $6.2 \%$ dry weight in Gracilaria domingensis, $4.6 \%$ dry weight in Laurencia intricate and $7.1 \%$ in Laurencia filiformis [77]. Chlorella produced high amounts of SCP, up to $45 \%$ of dry weight, which suggests the possibility of using algal biomass as substitute for conventional animal and vegetal protein sources [35]. Seasonal variations in micro-algae SCP production were also reported. Palmaria palmata gave the highest SCP yield ( $21.9 \%$ and $35 \%$ by dry weight) in winter/spring and lowest $(11.9 \%$ and $8 \%$ by dry weight) in summer/early autumn $[80,85]$. Seasonal variations were reported of between $7 \%$ and $23 \%$ of dry weight for Gracilaria verrucose and between $15 \%$ and $37 \%$ of dry weight for Porphyra umbilicalis [85].

Based on recent Algal SCP research, Chlorella sp (up to 52\%) and Spirulina (up to 56\%) proved able to offer the highest protein content, while also providing healthy lipids and being seen as environmentally friendly and very "green." It can be concluded that certain types of microalgae are successfully cultivated for animal and human consumption and 
usually have healthy protein contents. Apart from the proteins, they are excellent sources of fats, mainly omega-3 fatty acids, mineral salts, vitamins and chlorophyll [86].

\section{Fungal Metabolism}

A series of specific reactions characterize fungal metabolism. The catabolic processes consist in the biosynthesis of a large number of compounds, usually divided into primary and secondary metabolites [87]. The primary fungal metabolites, such as alcohols, organic acids (citric and lactic acid) and amino acids (L-glutamate, L-lysine) are required for growth and reproduction. The secondary metabolites are not essential for cellular life, but have importance from an ecological point of view, because they are involved in versatile metabolic pathways and have the capacity to break down organic matter, which cannot otherwise be recycled $[88,89]$. These secondary metabolites are natural compounds, such as small peptides, amino acids, pigments and products with a potentially toxic action, such as mycotoxins and antibiotics [90-93].

The precursors of the primary metabolites of SCP are intermediate molecules involved in anabolic and catabolic pathways that may be used for the synthesis of macromolecular subunits (lipids, amino acids, nucleotides) and/or may be oxidized to generate ATP. Glucose and pyruvate (Figure 4) are used for the biosynthesis of fungal secondary metabolites. They are linked together as result of reactions catalyzed by enzymes such as dimethyl-allyl tryptophan synthetases (DMATSs), polyketide synthases (PKSs), terpene cyclases (TCs) or non-ribosomal peptide synthetases (NRPSs). Oligomers result from these reactions, which are often chemically modified by the action of tailoring enzymes controlled by transcriptional regulation [94]. Macromolecular biosynthesis consists in lipids and amino acids, which are the main nutritional components of biomass.

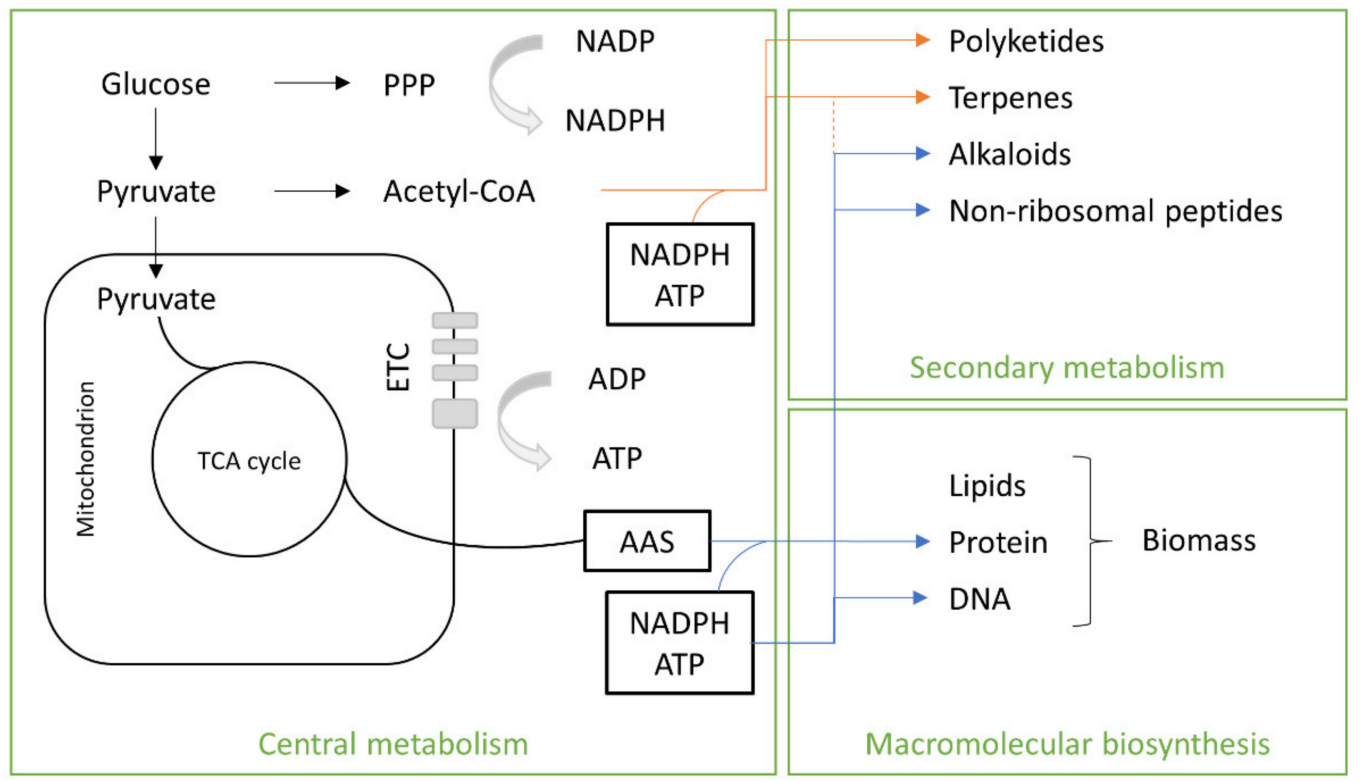

Figure 4. Fungal metabolism. TCA, tricarboxylic acid; ETC, electron transport chain.

\section{Fungal Sources}

Many fungal species are used to produce SCP (Table 3). Some fungal sources, such as Pleurotus floria, Aspergillus niger and Fusarium venenatum, are preferred due to their high protein content [95]. Fungi contain up to $63 \%$ protein when they are cultivated mainly for SCP production. Their amino acid profiles also meet the standards of the FAO concerning protein and amino acid in human nutrition [71]. Fungi proteins are rich in lysine and threonine but deficient in the sulfur-containing amino acids cysteine and methionine [71]. SCP obtained from fungi can also provide vitamin B-complex such as riboflavin, niacin, 
thiamine, biotin, pantothenic acid, choline, pyridoxine, glutathione, amino benzoic acid, streptogramin and folic acid [96]. Fungi have a relatively high nucleic acid content (up to $10 \%$ ) compared to algae (up to $6 \%$ ) [71,97].

Table 3. Fungal SCP production from different substrates.

\begin{tabular}{cccc}
\hline Fungi & Substrate & SCP (\%) & Reference \\
\hline Cladosporium cladosporioides & Rice bran & $10 \%$ & {$[98]$} \\
Penicillium citrinum & Rice bran & $10 \%$ & {$[98]$} \\
Pleurotus florida & Wheat straw & $63 \%$ & {$[99]$} \\
Chrysonilia sitophilia & Lignin & $39 \%$ & {$[100]$} \\
Aspergillus flavus & Rice bran & $10 \%$ & {$[98]$} \\
Aspergillus niger & Apple pomace & $17-20 \%$ & {$[101]$} \\
Aspergillus niger & Banana waste & $18 \%$ & {$[102]$} \\
Aspergillus niger & Rice bran & $11 \%$ & {$[98]$} \\
Aspergillus niger & Citrus pulp & {$[103]$} \\
Aspergillus niger & Potato starch processing waste & $38 \%$ & {$[29,30]$} \\
Aspergillus niger & Waste liquor & {$[104]$} & {$[98]$} \\
Aspergillus ochraceus & Rice bran & $10 \%$ & {$[95]$} \\
Aspergillus oryzae & Rice bran (deoiled) & $10 \%$ & {$[98]$} \\
Fusarium semitectum and sp1 and sp2 & Rice bran & $44 \%$ & {$[105]$} \\
Monascus ruber & Glucose (Product: Quorn ${ }^{\mathrm{TM}}$ ) & $9 \%$ & {$[98]$} \\
Trichoderma harzianum & Rice bran & $34 \%$ & {$[106]$} \\
Trichoderma virideae & Cheese whey filtrate & 32 & {$[103]$} \\
\hline
\end{tabular}

According to Baldensperger et al. (1985), the protein content of banana waste was raised from 6 to $18 \%$ by solid-state fermentation (SSF) using a strain of Aspergillus niger. Solar drying was used to make a green banana meal, and fermentation was carried out in a stirred reactor with a capacity of $15 \mathrm{~kg}$ (dry weight). Protein production was assessed to be $150 \%$ of the initial content because the substrate consumption was $24 \%$ of the starting weight after $43 \mathrm{~h}$ of fermentation. The fermented banana waste could be used as cattle feed because of its composition (50\% total sugars, 13\% reducing sugars and 18\% proteins) [102]. In their study, Liu et al. (2013) converted potato starch processing waste using a twostep process, namely, the degradation of fiber in potato residue with Aspergillus niger and fermentation with wastewater using Bacillus licheniformis. Protein accumulation was also carried out to produce SCP as animal feed. The main objective was to convert potato starch processing waste into SCP as animal feed and to increase the SCP quality. A protein content of $28 \%$ SCP was obtained under optimized conditions [30].

Valentino et al. (2016) produced SCP from nine fungi using a rice bran substrate. The fungi used were Cladosporium cladosporioides, Aspergillus ochraceus, Aspergillus niger, Aspergillus flavus, Penicillium citrinum, Monascus ruber, Fusarium semitectum, Fusarium sp1 and Fusarium sp2. The SCP production potential was evaluated through the crude protein content (CPC) accumulated after 20 days of SSF. Results indicated that inoculation of fungi increased the crude protein content of rice bran. Aspergillus niger had the highest CPC (10.63\%) followed by Aspergillus flavus (10.46\%), Aspergillus ochraceus (10.25\%), Fusarium semitectum $(10.25 \%)$ and Cladosporium cladosporioides $(9.69 \%)$. The uninoculated rice bran had the least CPC (9.53\%). Aspergillus niger, Aspergillus flavus, Aspergillus ochraceus and Fusarium semitectum produced the highest percentage increases, of $11.51 \%, 9.48 \%, 7.59 \%$ and $5.25 \%$, respectively. These results showed that endophytic fungi are good sources of SCP and enrich the CPC [98]. This study also evaluated the proximate composition of the rice bran. Results revealed a significant increase in the moisture, crude fiber, crude fat and ash content, while total energy and total carbohydrates decreased. Monascus-rubertreated rice bran obtained the highest protein content (9\%) [98]. Ahmadi et al. (2010) produced microbial protein by SSF, treating wheat straw with Pleurotus florida on a $2 \%$ $\mathrm{NaOH}$ substrate at $100{ }^{\circ} \mathrm{C}$. The concentration of protein was $62.8 \%$ [99]. Chiou et al. 
2001 reported 50\% protein content from Aspergillus niger using waste liqueur [104]. This approach can also recycle food-processing-plant waste into animal feed resources. Bhalla and Joshi (1994) analyzed the co-culture of cellulolytic molds and yeasts on apple pomace in SSF and liquid-state fermentation. Results showed an increased protein content of apple pomace. The co-culture of Candida utilis and Aspergillus niger increased the protein content of dried and pectin-extracted apple pomace to $20 \%$ and $17 \%$, respectively, under SSF conditions [101]. Ravinder et al. (2003) tested the growth of an industrially important fungus, Aspergillus oryzae, on deoiled rice bran through SSF technology. Among the various nitrogen sources tested, ammonium sulfate protein enrichment was $24.30 \%$, followed by vegetable and fruit waste extract with a $23.50 \%$ protein content [95]. Rodriguez et al. (1997) confirmed that Chrysonilia sitophilia can degrade considerable amounts of lignin. High protein (39\%) and low nucleic acid content indicates that Chrysonilia sitophilia SCP may be able to be used not only in animal fodder, but also as a potential food for humans [100]. Wiebe (2002) used glucose as a carbon source to produce SCP from Fusarium venenatum. The protein content was approximately $44 \%(w / w)$. This protein use-value is comparable to milk protein's use-value [105]. Şişman et al. (2013) evaluated the nutritional characteristics and possible toxic effects of the SCP from Trichoderma harzianum grown on whey filtrate agar medium and obtained SCP with $34.21 \%$ protein [106].

SCP and crude pectinolytic enzyme production from citrus pulp is reported by De Gregorio et al. (2002). SCP and enzymes were produced by slurry-state flask cultivation of Aspergillus niger and Trichoderma viride on pulp collected from lemon juice clarification. "The highest protein level was reached after 14 days growth with Aspergillus niger and 25 days growth with Trichoderma viride, though the final amount was higher in Trichoderma viride (31.9\%) than in Aspergillus niger (25.6\%) [103]."

\section{Yeast Metabolism}

In yeasts, the basic metabolic mechanisms are identical for different cells, but the resulting metabolites are different. Complex enzymatic reactions are involved in yeasts' metabolism. The metabolic process begins when the substrates penetrate the cell. Actionspecific factors then produce alterations of their basic structure [107]. The enzymatic reactions catalyzing the metabolic processes are needed for different aims: production and development of other cells, oxidation-reduction reactions which generate carbon dioxide and alcohol. Carbohydrates are the main carbon and energy source for most yeast species. However, there are known yeast species that use other sources of carbon, such as Cryptococcus aureus, Cryptococcus laurentii, Hannaella aff. zeae, Tremella encephala and Trichosporon coremiiforme [108]. These microorganisms have the capacity to form proteins and amino acids from simple nitrogenous sources as presented in Table 4.

The glycolysis process uses simple carbohydrates as substrates, mainly fructose and glucose. If other, more complex carbohydrates (maltotriose or maltose) are involved, they are hydrolyzed to glucose by $\alpha$-glucosidase. During the first step of the yeast's metabolic process, glucose is degraded to pyruvate, through glycolysis. The pyruvate metabolic pathway leads to the release of energy. Fermentation generates small amounts of energy, while respiration produces a larger amount (Figure 5). The carbon substrate is totally oxidated through respiration. Oxidative phosphorylation and the Krebs cycle are the mechanisms involved in this process. The energy produced and accumulated in ATP contributes to the generation of intermediary metabolites. In presence of oxygen, pyruvate enters into mitochondria where, under the action of the pyruvate dehydrogenase multienzyme system, it is the subject of the oxidative decarboxylation to acetyl-CoA. When yeasts are grown on two carbon sources (e.g., ethanol or acetate), the glyoxylate cycle, which may be considered a shortcut for the Krebs cycle, is often the supplier of energetic compounds. The alcoholic fermentation of carbohydrates involves a process whereby yeasts re-oxidize NADH to NAD. It is a two-step reaction: (1) pyruvate decarboxylase catalyzes the process of pyruvate decarboxylation, (2) alcohol dehydrogenase catalyzes 
the subsequent reaction of the reduction of acetaldehyde at the same time. Simultaneously, dihydroxyacetone phosphate generates glycerol.

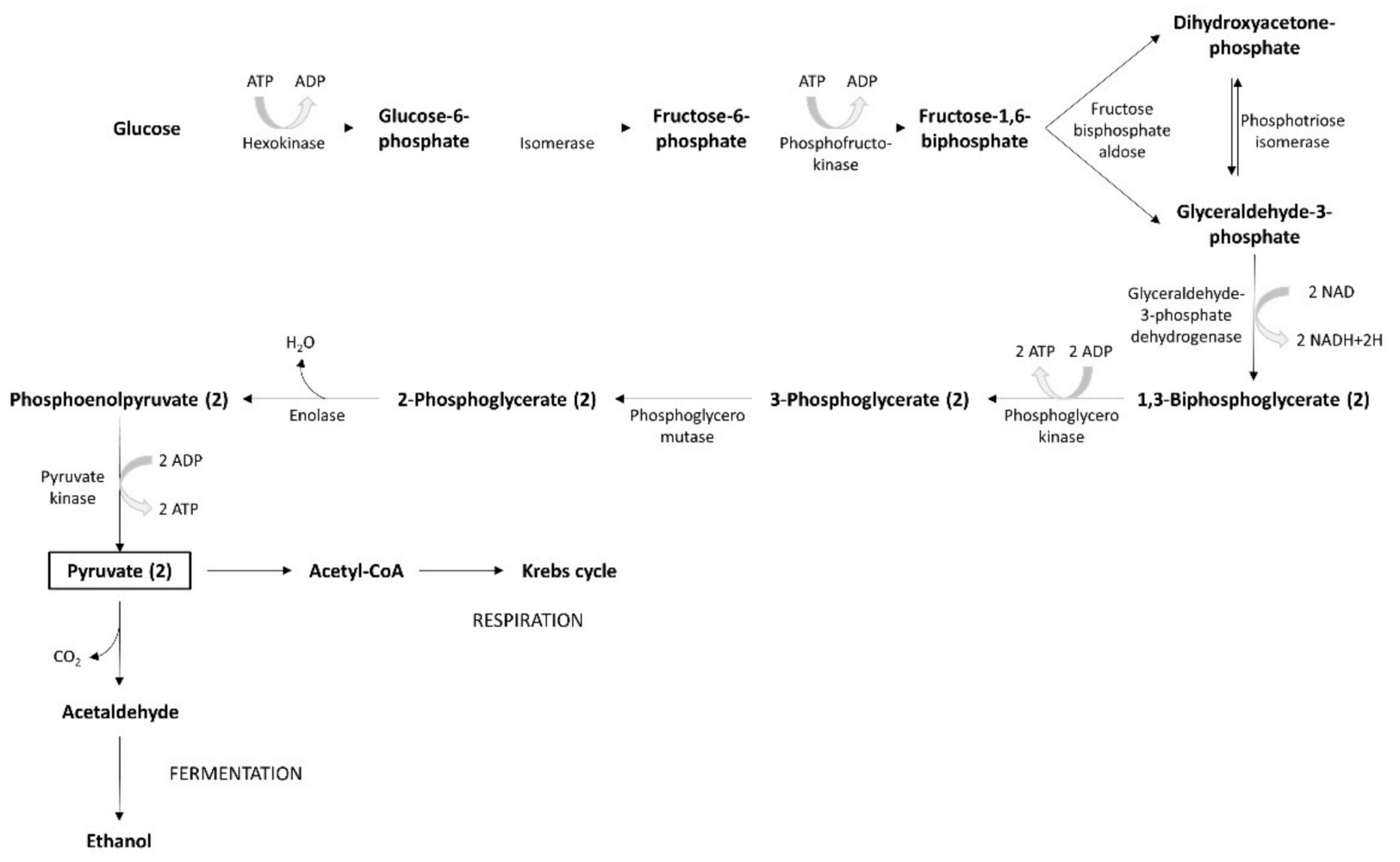

Figure 5. Glycolysis process.

Besides glycolysis, the pentose phosphate cycle or hexose phosphate pathway is an alternative way to glucose oxidation. This pathway provides the yeast cell with cytosolic NADPH and pentose carbohydrates, needed for production of amino acids, alcohols or fatty acids through biosynthetic reactions. This pathway has the following steps: (1) dehydrogenation of glucose-6-phosphate to 6-phosphogluconate and generation of one NADPH molecule, which is a reaction catalyzed by glucose-6-phosphate dehydrogenase; (2) the action of phosphogluconate dehydrogenase, which catalyzes the decarboxylation of 6-phosphogluconate, resulting ribulose-5-phosphate and a second molecule of NADPH. This pathway has two major functions: NADPH generation and the production of ribose carbohydrates used in the biosynthesis of nucleic acid precursors and nucleotide coenzymes. NAD and FAD, which are oxidation-reduction carriers, become reduced during the breakdown of carbohydrates to NADH and FADH2, but they are re-oxidized in the electron transport chain located in the mitochondrial membrane. The ATP synthase enzymatic system is also located in the mitochondrial membrane and catalyzes ATP formation from ADP and inorganic phosphate, but also the process of oxidative phosphorylation. The energy released during the transfer of electrons is connected with oxidative phosphorylation [109].

Anaerobic alcoholic fermentation involves the partial degradation of the substrate because it stops at the end of glycolysis, generating two molecules of pyruvate. It means that an incomplete oxidation of glucose occurs and this process provides low amounts of energy. Ethanol and carbon dioxide are the oxidation products of carbohydrates.

\section{Yeast Sources}

Yeast is a good source of SCP production and has been used for a long time, mainly due to its superior nutritional quality. In Germany during World War I, torula yeast (Candida utilis) was used in sausages and soups. At present, it is frequently used in animal feed as a fodder supplement ( $\operatorname{dog}$ and fish feed) and used as a seasoning in vegetarian 
foods [7]. Yeast cells are larger than bacterial cells, have high lysine and malic acid contents, low methionine and nucleic acid contents and are able to grow under acidic $\mathrm{pH}$ conditions [110]. Yeast has low growth rate and lower protein content $(65 \%)$ compared to bacteria $(80 \%)$ [71,111]. A variety of substrates and microbes have been used for SCP production; however, presence of toxic and carcinogenic compounds (aflatoxins of type B1, B2, G1 and G2, citrinin, trichothecenes and zearalenone) generated during the production process should always be considered. The two main limiting factors for yeast are the high nucleic acid content and low cell-wall digestibility [14,71,111].

Table 4. Yeast SCP production from different substrates.

\begin{tabular}{cccc}
\hline Yeast & Substrate & SCP (\%) & Reference \\
\hline Saccharomyces cerevisiae & Orange pulp, molasses, brewer's spent grain & 39 & {$[112]$} \\
Candida krusei & Cheese whey & 48 & {$[113]$} \\
Candida tropicalis & Molasses & 31 & {$[114]$} \\
Candida tropicalis & Bagasse & 29 & {$[115]$} \\
Candida utilis & Waste capsicum powder & 48 & {$[116]$} \\
Candida utilis & Poultry litter & 46 & {$[117]$} \\
Candida utilis & Potato starch industry waste & 49 & {$[30]$} \\
Candida utilis & Potato wastewater & 49 & {$[118]$} \\
Hanseniaspora uvarum & Spoiled date palm fruit & 54 & {$[119]$} \\
Kefir sp. & Cheese whey & 23 & {$[120]$} \\
Kefir sp. & Orange pulp, molasses, brewer's spent grain, & 32 & {$[112]$} \\
Debaryomyces hansenii & whey, potato pulp, malt spent & [121] \\
Kluyveromyces marxianus & Brewery's spent grains (hemicellulosic & 43 & {$[113]$} \\
Kluyveromyces marxianus & Crange pulp, molasses, brewer's spent grain, & 34 & {$[112]$} \\
Zygosaccharomyces rouxi & Chey, potato pulp & 49 & {$[119]$} \\
Yarrowia lipolytica & Inulin, crude oil, glycerol waste hydrocarbons & $48-54$ & {$[122]$} \\
\hline
\end{tabular}

A series of studies conducted worldwide show promising results concerning the possibility of using yeast as SCP, as reflected in Table 4. Studies performed by Aggelopoulos et al. (2014) on the growth of Kefir sp, Kluyveromyces marxianus and Saccharomyces cerevisiae by SSF using substrates composed of various kinds of common food industry waste (whey, molasses, brewer's solid waste and orange and potato residues) emphasize a protein content of 39\% in Saccharomyces cerevisiae, 34\% in Kluyveromyces marxianus and 23\% in Kefir $s p$ [112]. Another study analyzed a mixed culture of Kluyveromyces marxianus and Candida $k r u s e i$ to enhance chemical oxygen-demand removal efficiency, minimize contamination at extreme conditions (high temperature $\left(40{ }^{\circ} \mathrm{C}\right)$ and low $\mathrm{pH}$ (3.5)) during batch and continuous aerobic fermentation, and to obtain improvements in the quality of the SCP using whey as a substrate. The results show that the SCP content was $47.53 \%$ for Candida krusei and $43 \%$ for Kluyveromyces marxianus [113]. An effective bioprocess to produce SCP from soy molasses using Candida tropicalis was developed by Gao et al. (2012). This SCP contained $56.42 \%$ crude protein and 5.28\% nucleic acids. These results suggest that Candida tropicalis might be applied effectively to produce SCP using soy molasses as a low-cost substrate [114]. Jalasutram et al. (2013) reported $48 \%$ protein content from digested and undigested poultry litter by Candida utilis [117]. Research on sugar cane bagasse used as a substrate to grow Candida tropic in a $1.0-1$ bioreactor at $30^{\circ} \mathrm{C}$ and a pH of 6.0. showed that the protein produced (31.3\% of the total biomass) contained essential amino acids (lysine, histidine, arginine, aspartic acid, threonine, serine, glutamic acid, proline, glycine, alanine, cysteine, valine, methionine, isoleucine, leucine, tryptophan, tyrosine, phenylalanine) for animal feeding [115]. Capsicum powder medium contained sufficient nutrients and could be used as a good medium to produce SCP, while Candida utilis yeast used to produce microbial biomass yielded a protein content of $29 \%$. Utilization of waste capsicum powder 
can reduce environmental pollution produced by waste generation by converting it to use in animal feed [116]. Liu et al. (2013) conducted a study to reduce the pollution of the waste produced by the potato starch industry and transform the potato pulp and wastewater into SCP which could ultimately be used as animal feed. Results show that Candida utilis cultured in potato dextrose medium and potato wastewater at $28{ }^{\circ} \mathrm{C}$ for $48 \mathrm{~h}$ led to a protein content of 46\% [30] and 49\% [118], respectively. Hashem at al. (2014) used two yeast strains Hanseniaspora uvarum and Zygosaccharomyces rouxii from spoiled date fruits for single cell protein production. Both strains were assessed for SCP productivity in vitro and in a bioreactor. The highest production $(48.9 \mathrm{~g} / \mathrm{L})$ of the two strains was achieved after $60 \mathrm{~h}$ [119]. Paraskevopoulou et al. (2003) produced SCP (53.9\% protein) using the aerobic fermentation of cheese whey by Kefir microorganisms. The experiments were conducted under controlled $\mathrm{pH}(5.5)$ and temperature $\left(30^{\circ} \mathrm{C}\right)$ conditions [120]. Cui et al. (2011) reported that Yarrowia lipolytica is suitable for producing SCP from inulin and inulincontaining materials, obtaining a protein content of between $48-54 \%$ [122]. SCP production from Debaryomyces hansenii yeast biomass using brewer's spent grains (hemicellulosic) as a carbon source was demonstrated by Duarte et al. (2008). The total protein content obtained was 32\% [121]. Certain yeasts have been successfully used to produce SCP from alkanes, such as Saccharomycopsis lipolytica, Candida tropicalis and Candida oleophila. The major drawback of alkanes as a substrate is the formation of carcinogen compounds, which are highly harmful.

\section{Nutritional Benefits of SCP}

Wu et al. (2014) indicated that the worldwide human protein diet is $65 \%$ plant based and 35\% animal based [123]. The average meat intake per capital is projected to rise by $29 \%$, from $40.0 \mathrm{~kg}$ in 2013 to $51.5 \mathrm{~kg}$ in 2050 . Global meat production is therefore expected to increase from 288 million tons in 2013 to 494 million tons by 2050. According to previous research, SCP could be a valuable solution for suppling the global demand of protein, due to its low cost of production, easy process and nutritional quality $[8,11,71,124]$.

As previously stated, the primary goal of SCP production is to use it as a protein (meat) substitute to address food scarcity and hunger in the near future. SCP must meet nutritional requirements to be consumed as human food or animal feed, such as the required protein content, amino acid composition of the protein being generated and digestibility of that protein. According to the researchers, SCP must be produced to the highest standards to be safe and beneficial for food and feed [125].

Finnigan et al. (2017) defined some of the macro and micronutrients provided by SCP as follows: proteins, lipids, carbohydrates, $\beta$-carotene, vitamin A precursor, biotin, folic acid, niacin, pantothenic acid, pyridoxine, riboflavin, thiamine, vitamin B12 (cyanocobalamin), vitamin C and vitamin E [126].

Beside its protein content, the nutritional value of SCP depends on its chemical composition (amino acids, nucleic acids minerals, enzymes and vitamins) but it is relatively cheap compared to other plant and animal sources [127]. It was reported that dried cells of Pseudomonas spp. grown on petroleum-based liquid paraffin contain as much as 69\% protein. SCP obtained by algae processing is about $40 \%$. Though proteins obtained from microbes contain all essential amino acids, their composition depends on the type of substrate used (carbon or nitrogen) and the type of microorganism grown on a specific medium [128]. Microorganisms like bacteria and yeast have a very short multiplication time as they double their population in just 5-15 min, while algae and mold species double themselves in $2-4 \mathrm{~h}$. The amino acid profile of SCP from bacteria shows a close resemblance to fish protein and protein from yeast resembles soya protein [129]. In addition, SCP is reported to be deficient in sulfur-containing amino acids such as methionine and cysteine, whereas high levels of lysine and other amino acids have been observed. Supplementation of methionine and cysteine is required for the use of SCP as a feed ingredient. Microorganisms normally contain vitamin B12 in significant quantities. Bacteria and algae are reported with high vitamin B12 and vitamin A content, respectively [130]. Most common vitamins present 
in SCP are riboflavin, thiamine, pyridoxine, niacin choline, folic acid, pantothenic acid, biotin, para-amino benzoic acid, inositol and B12 [130]. Most microorganisms have very fast growth rate that yields a high amount of biomass (algae: 3-6 h, bacteria: $30 \mathrm{~min}$ to $2 \mathrm{~h}$, yeast: $40 \mathrm{~min}$ to $3 \mathrm{~h}$ ) [71]. These microorganisms can be used as a whole in contrast to most crop and animal protein sources which cannot be used entirely [131]. SCP produced from different microbes has high protein content (30-70\%) as compared to different green plants and animal sources [86]. Moreover, these proteins have an excellent amino acid profile that makes them nutritionally more useful than conventional protein sources [132]. Nevertheless, scientists can add more valuable amino acids to proteins through genetic engineering, obtaining SCP with the desired composition. Some microorganisms during the course of SCP production produce significant amounts of vitamins which cannot be produced by the host individual in appropriate amounts. Production of SCP also requires low water content as compared to plant sources [133]. Unlike plant protein sources, SCP is independent of environmental and climatic variation and can be produced throughout the year as microbes are available round the clock. The shelf life of protein preparation is dependent on the nature of the protein and the storage conditions used, and can vary from a few days to more than a year. Optimal conditions for storage are distinctive to each protein.

Nutritive and food values of SCP vary with the microorganisms used. The microorganisms used for SCP production must be non-pathogenic, toxin-free, easy to handle and separate from the substrate and should also tolerate the scaling-up of the process. Fast-growing microorganisms are required for getting massive output (biomass weight produced per unit time). However, high output produces more quantities of RNA in the cell, and this is not desirable as it acts as anti-nutritional factor in the final product. The method of harvesting, drying and processing affects the nutritive value of the finished product [134-138]. The idea that SCP could help to overcome food shortages in developing countries has garnered interest among scientists and industry. For future success of SCP, food technology problems must be solved to make these foods familiar, while the production should compare favorably with other protein sources.

The raw materials for SCP production based on waste substances are cheap, readily available and their processing contributes to reducing environmental pollution. The origin of the feedstock must be carefully selected. Various types of raw materials are attractive sources for SCP production from a cost and sustainability perspective but may raise safety concerns. In addition to the safety requirements, the use of other unconventional wastederived protein sources in human nutrition requires efforts to improve public perception and acceptance and increase consumer awareness of the benefits of SCP consumption in human diets.

Yeast SCPs have been used in aquaculture diets as partial replacement for fishmeal, thanks to their excellent nutrient profiles and cost-effective large-scale production [138,139], and have also been applied for the highly unsaturated fatty acid fortification of Artemia and rotofiers [137]. Some yeast strains with probiotic properties, such as Saccharomyces cerevisiae [140] and Debaryomyces hansenii [141], increased larval survival by early maturation of the pancreas and intestine [141]. However, many of these yeast SCPs are deficient in sulfated amino acids, e.g., methionine [140], thus, cannot be used as sole protein sources. Micro-algal SCP may be used for both animal and human consumption, and their nutritional value is similar to, and sometimes higher than, values reported for conventional food/feed supplements. Besides their high protein content, they are a source of nucleic acids (up to $6 \%$ ), minerals (sodium, magnesium, potassium, iodine) and vitamins (A, B group, D, C and E) and essential amino acids (leucine, valine, lysine, phenylalanine) [97] (Figure 6). Compared to many vegetable foods, micro-algae SCP contains higher amounts of vitamins such as riboflavin, thiamine, folic acid or pro-vitamins as carotene [73]. Microalgae, as Spirulina and Chlorella, are sources of vitamin B12 (cyanocobalamin), which otherwise has animals as almost exclusive source [73]. Algal SCP has a nutritional value like other SCP sources. The crude protein content ( $\mathrm{N} 6.25)$ varies between 45 and $73 \%$, 
while the lipid content is $2-20 \%$ and is rich in essential fatty acids, and the mineral content is $5-10 \%$. The protein content of algae is higher than the value for soybean $(70 \%$ and $40 \%$, respectively), and its amino acid profile shows an adequate balance except, as for any other microbial biomass, for the sulfur-containing amino acids methionine and cysteine [71,73]. Algal SCP is a good source of vitamins A, B group, D, C and E; the content of some vitamins such as thiamine, riboflavin, folic acid and carotene is higher in algae than in many vegetable foodstuffs. Some microalgae, such as Chlorella and Spirulina, contain vitamin B12 (cyanocobalamin), which is found almost exclusively in animal origin foods. The content of nutrients, however, is highly dependent on cultivation and processing conditions [73]. In addition, the search for new insects as a source of protein and the related technology for processing requires further research.

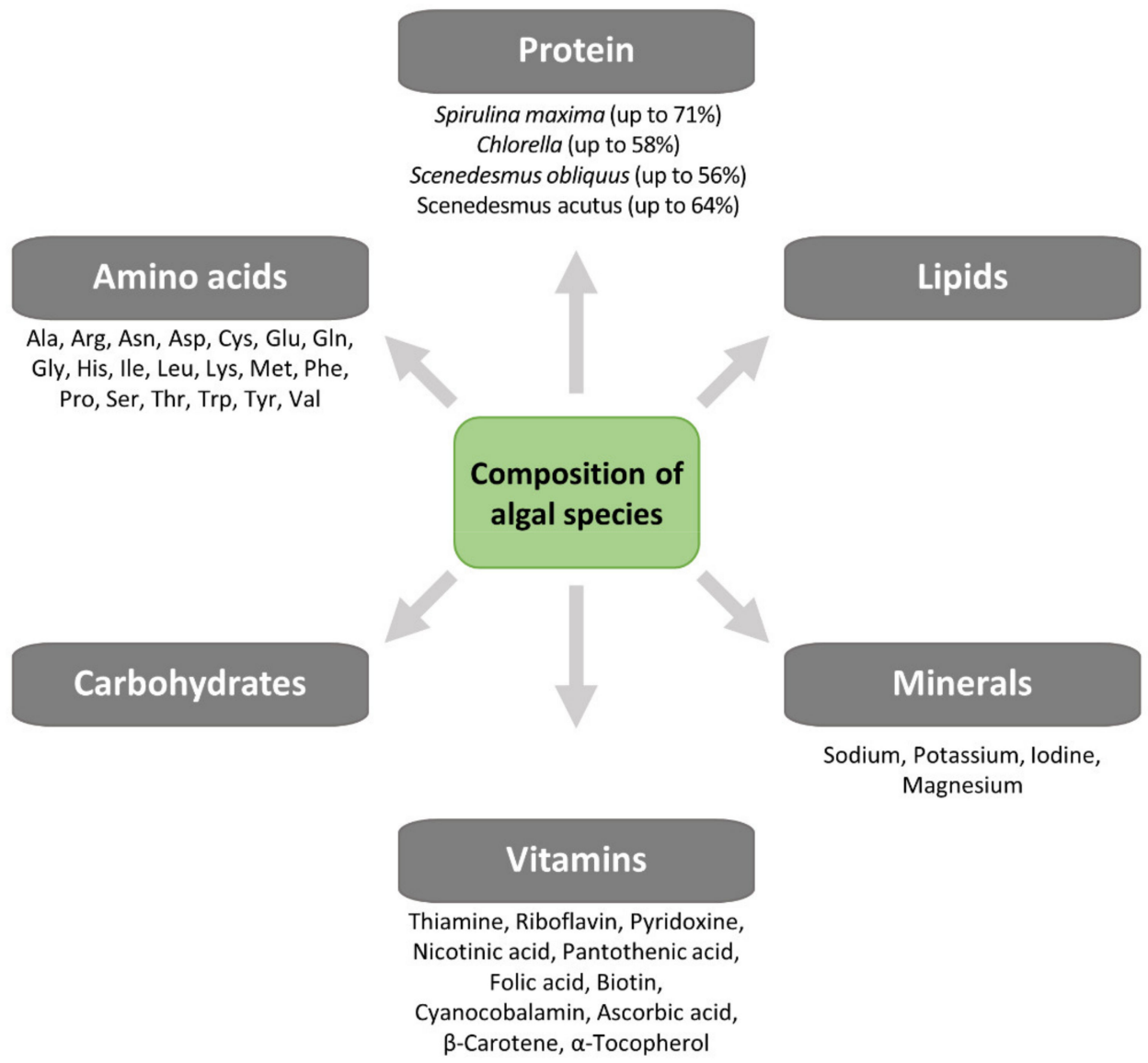

Figure 6. Composition of algal species.

Due to its efficiency requirements (low-cost production, protein quality, easy process), SCP production is not an easy task, and the obtained end-product might also raise some potential limitations. A key challenge for the industry is sourcing a sustainable, renewable high-protein ingredient. SCP contains up to $16 \%$ nucleic acids [97]. This may be a problem when SCP is destined for human consumption because the recommended nucleic acid dose in human nutrition is below $2 \%$. Purines resulting from nucleic acid breakdown during human metabolic processes are responsible for the potential harmful effects of high nucleic acid by raising the uric acid levels in plasma, which can lead to gout and kidney stones [71]. The process of converting SCP to a consumable food for humans also requires the additional development of aroma and taste, which is certainly not cost-effective and makes the process less efficient [76]. SCP can cause allergic reactions for some humans who have a sensitive digestive system or if their body refuses to recognize the biomass [3]. Moreover, waste materials used as substrates in SCP production may contain unknown substances which could raise other health issues [76]. 


\section{Economic Analysis}

SCP production can be a profitable business if certain tactics for economic production are used. The following categories/processes are included in the costs for its production [3,142]: the cost of raw materials and chemicals/enzymes needed for pretreatment of substrates, particularly lignocellulosic waste, the cost of reducing agents for strict anaerobes and the cost of scaling up the fermentation process. The cost of this scale-up is directly reflected in the cost of the final product. Thus, a continuous fermentation process is preferable for the industrial production of SCP, as this is the most profitable strategy. In a study conducted by Junaid et al. (2020), the product cost, capital investment and profit obtained from the product were used to determine the economic viability of SCP production. To achieve this goal an improvement of the strains of microorganisms, better fermentation methods and advanced down-streaming methods are needed.

Economic analysis performed by Liu et al. (2014) indicated that the processing of potato waste could simplify not only the pollution problem in the starch industry, but also the shortage of protein for animal feed in China [29]. SCP microorganisms incorporate most nutrients fed to them into the final harvested biomass. SCP could replace soybean meal and other protein supplements used in animal feed, such as meat meal and fishmeal. Offsets from these sources would create different environmental and economic incentives. Fishmeal is priced at almost five times the price of soybean meal, at $\$ 1500 /$ ton versus $\$ 320 /$ ton [143]. SCP production from food waste is another promising microbial technology that may yield better outcomes as a food-waste management strategy over anaerobic digestion.

\section{Conclusions}

Researchers and businesses from all over the world are interested in SCP production Thanks to the multiple promising benefits that these proteins provide, various firms have sprouted up that claim to be able to commercialize SCP. However, a key challenge for the industry is sourcing a sustainable, renewable protein-enriched ingredient. Currently, fishmeal, along with terrestrial plant meals, makes up most of the protein content of diets.

Among others, algae, fungi, yeast and bacteria can be utilized for SCP production but each have their own advantages and disadvantages. Bacteria possess higher growth rates, higher protein content and more sulfur-containing amino acids. From an industrial perspective, methane-oxidizing bacteria are the most advanced and market-ready bacteria for SCP production. Yeasts have been used as a source of SCP for a long time. SCP from fungi has been found to be useful in animal feed, while specific byproducts are employed in the beverage sector. Single cell algae have a high growth rate, protein content (up to $70 \%$ ), and chlorophyll; contain bile pigments, fiber and mineral salts; and have a lower nucleic acid content (4-6\%) compared with fungi (9.7\%) and bacteria (16\%). As well as providing lipids that are beneficial for human nutrition, algal SCP is a good source of vitamins, as the content of some vitamins such as thiamine, riboflavin, folic acid and carotene is higher in algae than in many vegetable foodstuffs. Some of these microalgae, like Chlorella and Spirulina, include vitamin B12 (cyanocobalamin), which is almost exclusively found in animal-derived diets. Nutrient content, on the other hand, is greatly reliant on growing and processing circumstances. Although it has very attractive characteristics, SCP also presents some challenges that must be be considered, such as production cost and growth conditions, but most importantly, the higher concentration of nucleic acid in SCP than in other conventional protein sources, which is its main anti-nutritional factor. There is still a lot of work to be done on this subject to reap as many benefits of SCP as possible, but several challenges described above can be avoided by improving the strains of microorganisms, carefully optimizing the fermentation protocol during production and implementing advanced down-streaming methods. Moreover, the selection of active microorganisms along with a suitable substrate is helpful in counteracting the above limitations and makes the usage of SCP beneficial. Furthermore, anti-nutritional factors, 
i.e., nucleic acids, can be removed by applying different physical and chemical treatments during processing.

SCP exhibits very attractive characteristics as a nutrient supplement for both animals and plants. It can be produced at any time in the year because of its independence from seasonal and climatic variations. It could be produced from various cost-free substrates. Therefore, it can easily replace conventional animal and protein sources in both humans and animal diets without any negative impact.

Author Contributions: Conceptualization, D.C.V., S.D.; B.C.B. wrote the first draft; D.C.V. revised the paper and conceptualized the subtitles about single cell protein substrates; D.C.V. and B.C.B. revised the draft and the final form; S.D. helped in gathering data and discussions. All authors have read and agreed to the published version of the manuscript.

Funding: This work was supported by the National Research, Development, and Innovations Program for 2015-2020-PNII, developed with the support of UEFISCDI (Project No. PN-III-P1-1.1-TE2019-1748; 184TE).

Institutional Review Board Statement: Not applicable.

Informed Consent Statement: Not applicable.

Data Availability Statement: Not applicable.

Conflicts of Interest: The authors declare no conflict of interest.

\section{References}

1. Pihlajaniemi, V.; Ellilä, S.; Poikkimäki, S.; Nappa, M.; Rinne, M.; Lantto, R.; Siika-aho, M. Comparison of pretreatments and cost-optimization of enzymatic hydrolysis for production of single cell protein from grass silage fibre. Bioresour. Technol. Rep. 2020, 9, 100357. [CrossRef]

2. Verstraete, W.; Clauwaert, P.; Vlaeminck, S.E. Used water and nutrients: Recovery perspectives in a 'panta rhei' context. Bioresour. Technol. 2016, 215, 199-208. [CrossRef] [PubMed]

3. Ritala, A.; Häkkinen, S.T.; Toivari, M.; Wiebe, M.G. Single Cell Protein-State-of-the-Art, Industrial Landscape and Patents 2001-2016. Front. Microbiol. 2017, 8. [CrossRef] [PubMed]

4. World Health Organization. The State of Food Security and Nutrition in the World 2020: Transforming Food Systems for Affordable Healthy Diets; Food and Agriculture Organization: Rome, Italy, 2020.

5. Food and Agricultural Organization of the United Nations. How to Feed the World in 2050. Available online: http://www.fao. org/fileadmin/templates/wsfs/docs/expert_paper/How_to_Feed_the_World_in_2050.pdf (accessed on 18 June 2021).

6. Junaid, F.; Khawaja, L.A.; Ali, S. Single cell proteins as a potential meat substitute: A critical review. World J. Pharm. Res. 2020, 9, 141-161. [CrossRef]

7. Srividya, A.R.; Vishnuvarthan, V.J.; Murugappan, M.; Dahake, P.G. Single Cell Protein- A Review. Int. J. Pharm. Res. Sch. 2013, 2, $472-485$.

8. Suman, G.; Nupur, M.; Anuradha, S.; Pradeep, B. Single Cell Protein Production: A Review. Int. J. Curr. Microbiol. Appl. Sci. 2015, 4, 251-262.

9. Zhou, Y.-M.; Chen, Y.-P.; Guo, J.-S.; Shen, Y.; Yan, P.; Yang, J.-X. Recycling of orange waste for single cell protein production and the synergistic and antagonistic effects on production quality. J. Clean. Prod. 2019, 213, 384-392. [CrossRef]

10. Nagare, B.; Bhambere, S.; Kumar, S.; Kakad, K.; Nagare, N. In Situ Gelling System: Smart Carriers for Ophthalmic Drug Delivery. Int. J. Pharm. Res. Sch. 2015, 4, 10-23.

11. Yunus, F.-u.-N.; Nadeem, M.; Rashid, F. Single-cell protein production through microbial conversion of lignocellulosic residue (wheat bran) for animal feed. J. Inst. Brew. 2015, 121, 553-557. [CrossRef]

12. Matassa, S.; Boon, N.; Pikaar, I.; Verstraete, W. Microbial protein: Future sustainable food supply route with low environmental footprint. Microb. Biotechnol. 2016, 9, 568-575. [CrossRef]

13. Ali, S.; Mushtaq, J.; Nazir, F.; Sarfraz, H. Production and Processing of Single Cell Protein (SCP)—A review. Eur. J. Pharm. Med. Res. 2017, 4, 86-94.

14. Raziq, A.; Lateef, M.; Ullah, A.; Ullah, H.; Khan, M.W. Single cell protein (SCP) production and potential substrates: A comprehensive review. Philipp. Accredit. Bur. 2020, 9. [CrossRef]

15. Queiroz, M.I.; Lopes, E.J.; Zepka, L.Q.; Bastos, R.G.; Goldbeck, R. The kinetics of the removal of nitrogen and organic matter from parboiled rice effluent by cyanobacteria in a stirred batch reactor. Bioresour. Technol. 2007, 98, 2163-2169. [CrossRef]

16. Kadim, I.T.; Mahgoub, O.; Baqir, S.; Faye, B.; Purchas, R. Cultured meat from muscle stem cells: A review of challenges and prospects. J. Integr. Agric. 2015, 14, 222-233. [CrossRef]

17. Zepka, L.Q.; Jacob-Lopes, E.; Goldbeck, R.; Queiroz, M.I. Production and biochemical profile of the microalgae Aphanothece microscopica Nägeli submitted to different drying conditions. Chem. Eng. Process. 2008, 47, 1305-1310. [CrossRef] 
18. John, R.P.; Anisha, G.S.; Nampoothiri, K.M.; Pandey, A. Micro and macroalgal biomass: A renewable source for bioethanol. Bioresour. Technol. 2011, 102, 186-193. [CrossRef]

19. Zha, X.; Tsapekos, P.; Zhu, X.; Khoshnevisan, B.; Lu, X.; Angelidaki, I. Bioconversion of wastewater to single cell protein by methanotrophic bacteria. Bioresour. Technol. 2021, 320, 124351. [CrossRef]

20. Jurtshuk, P.J. Bacterial Metabolism. In Medical Microbiology, 4th ed.; Baron, S., Ed.; University of Texas Medical Branch at Galveston: Galveston, TX, USA, 1996; Chapter 4.

21. Vasdekis, A.E.; Stephanopoulos, G. Review of methods to probe single cell metabolism and bioenergetics. Metab. Eng. 2015, 27, 115-135. [CrossRef]

22. Müller, W.E.G.; Schröder, H.C.; Wang, X. Inorganic Polyphosphates As Storage for and Generator of Metabolic Energy in the Extracellular Matrix. Chem. Rev. 2019, 119, 12337-12374. [CrossRef] [PubMed]

23. Garimella, S.; Kugle, K.; Kssoju, A.; Merugu, R. Current status on single cell protein (SCP) production from photosynthetic purple non sulfur bacteria. J. Chem. Pharma. Sci. 2017, 10, 915-922.

24. Bamberg, J. British Petroleum and Global Oil 1950-1975. The Challenge of Nationalism; Cambridge University Press: Cambridge, UK, 2000.

25. Øverland, M.; Tauson, A.-H.; Shearer, K.; Skrede, A. Evaluation of methane-utilising bacteria products as feed ingredients for monogastric animals. Arch. Anim. Nutr. 2010, 64, 171-189. [CrossRef]

26. Carrillo, W. Biotechnology and Food Production; ED-Tech Press: Essex, UK, 2020.

27. Chumpol, S.; Kantachote, D.; Nitoda, T.; Kanzaki, H. Administration of purple nonsulfur bacteria as single cell protein by mixing with shrimp feed to enhance growth, immune response and survival in white shrimp (Litopenaeus vannamei) cultivation. Aquaculture 2018, 489, 85-95. [CrossRef]

28. Kurbanoglu, E.B.; Algur, O.F. Single-cell protein production from ram horn hydrolysate by bacteria. Bioresour. Technol. 2002, 85, 125-129. [CrossRef]

29. Liu, B.; Li, Y.; Song, J.; Zhang, L.; Dong, J.; Yang, Q. Production of single-cell protein with two-step fermentation for treatment of potato starch processing waste. Cellulose 2014, 21,3637-3645. [CrossRef]

30. Liu, B.; Song, J.; Li, Y.; Niu, J.; Wang, Z.; Yang, Q. Towards industrially feasible treatment of potato starch processing waste by mixed cultures. Appl. Biochem. Biotechnol. 2013, 171, 1001-1010. [CrossRef]

31. Wongputtisin, P.; Khanongnuch, C.; Kongbuntad, W.; Niamsup, P.; Lumyong, S.; Sarkar, P.K. Use of Bacillus subtilis isolates from Tua-nao towards nutritional improvement of soya bean hull for monogastric feed application. Lett. Appl. Microbiol. 2014, 59, 328-333. [CrossRef] [PubMed]

32. Wang, J.P.; Kim, J.D.; Kim, J.E.; Kim, I.H. Amino acid digestibility of single cell protein from Corynebacterium ammoniagenes in growing pigs. Anim. Feed Sci. Technol. 2013, 180, 111-114. [CrossRef]

33. Kunasundari, B.; Murugaiyah, V.; Kaur, G.; Maurer, F.H.J.; Sudesh, K. Revisiting the Single Cell Protein Application of Cupriavidus necator H16 and Recovering Bioplastic Granules Simultaneously. PLoS ONE 2013, 8, e78528. [CrossRef]

34. Taran, M.; Asadi, N. A Novel Approach for Environmentally Friendly Production of Single Cell Protein From Petrochemical Wastewater Using a Halophilic Microorganism in Different Conditions. Petrol. Sci Technol. 2014, 32, 625-630. [CrossRef]

35. Rasouli, Z.; Valverde-Pérez, B.; D’Este, M.; De Francisci, D.; Angelidaki, I. Nutrient recovery from industrial wastewater as single cell protein by a co-culture of green microalgae and methanotrophs. Biochem. Eng. 2018, 134, 129-135. [CrossRef]

36. Xu, M.; Zhou, H.; Yang, X.; Angelidaki, I.; Zhang, Y. Sulfide restrains the growth of Methylocapsa acidiphila converting renewable biogas to single cell protein. Water Res. 2020, 184, 116138. [CrossRef]

37. Yazdian, F.; Hajizadeh, S.; Shojaosadati, S.A.; Khalilzadeh, R.; Jahanshahi, M.; Nosrati, M. Production of single cell protein from natural gas: Parameter optimization and RNA evaluation. Iran. J. Biotechnol. 2005, 3, 235-242.

38. Lee, J.Z.; Logan, A.; Terry, S.; Spear, J.R. Microbial response to single-cell protein production and brewery wastewater treatment. Microb. Biotechnol. 2015, 8, 65-76. [CrossRef] [PubMed]

39. Kornochalert, N.; Kantachote, D.; Chaiprapat, S.; Techkarnjanaruk, S. Use of Rhodopseudomonas palustris P1 stimulated growth by fermented pineapple extract to treat latex rubber sheet wastewater to obtain single cell protein. Ann. Microbiol. 2014, 64, 1021-1032. [CrossRef]

40. Getha, K.; Vikineswary, S.; Chong, V.C. Isolation and growth of the phototrophic bacterium Rhodopseudomonas palustris strain B1 in sago-starch-processing wastewater. World J. Microbiol. Biotechnol. 1998, 14, 505-511. [CrossRef]

41. Ponsano, E.H.G.; Lacava, P.M.; Pinto, M.F. Chemical composition of Rhodocyclus gelatinosus biomass produced in poultry slaughterhouse wastewater. Braz. Arch. Biol. Technol. 2003, 46, 143-147. [CrossRef]

42. Noparatnaraporn, N.; Nagai, S. Selection of Rhodobacter sphaeroides P47 as a useful source of single cell protein. J. Gen. Appl. Microbiol. 1986, 32, 351-359. [CrossRef]

43. He, J.; Zhang, G.; Lu, H. Treatment of soybean wastewater by a wild strain Rhodobacter sphaeroides and to produce protein under natural conditions. Front. Environ. Sci. Eng. 2010, 4, 334-339. [CrossRef]

44. Suwansaard, M. Production of Hydrogen and 5-Aminolevulinic Acid by Photosynthetic Bacteria from Palm Oil Mill Effluent. Prince of Songkla University. 2010. Available online: https:/ / kb.psu.ac.th/psukb/handle/2016/10300 (accessed on 22 June 2021).

45. Balloni, W.; Carlozzi, P.; Ventura, S.; Sacchi, A. Microbial biomass for fertilizer use from the photo-anaerobic treatment of pig-wastes. In Proceedings of the International Symposium on Compost Recycling of Wastes, Udine, Italy, 17-19 April 1986. 
46. Balloni, W.; Carlozzi, P.; Ventura, S.; De Phillipis, R.; Bosco, M. A three years experiment on the production of Rhodopseudomonas and Rhodospirillum biomass by outdoor culture on different wastes. In Proceedings of the 4th International Conference on Biomass for Energy and Industry, Orleans, France, 11-15 May 1987.

47. Sasaki, K.; Noparatnaraporn, N.; Hayashi, M.; Nishizawa, Y.; Nagai, S. Single cell protein production by treatment of soybean wastes with Rhodopseudomonas gelatinos. J. Ferment. Technol. 1981, 59, 471-477.

48. Prasertsan, P.; Choorit, W.; Suwanno, S. Isolation, identification and growth conditions of photosynthetic bacteria found in seafood processing wastewater. World J. Microbiol. Biotechnol. 1993, 9, 590-592. [CrossRef]

49. Kar Soon, T.; Al-Azad, S.; Ransangan, J. Isolation and characterization of purple non-sulfur bacteria, Afifella marina, producing large amount of carotenoids from mangrove microhabitats. J. Microbiol. Biotechnol. 2014, 24, 1034-1043. [CrossRef]

50. Whangchenchom, W.; Chiemchaisri, W.; Tapaneeyaworawong, P.; Powtongsook, S. Wastewater from Instant Noodle Factory as the Whole Nutrients Source for the Microalga Scenedesmus sp. Cultivation. Environ. Eng. Res. 2014, 19, 283-287. [CrossRef]

51. Saejung, C.; Thammaratana, T. Biomass recovery during municipal wastewater treatment using photosynthetic bacteria and prospect of production of single cell protein for feedstuff. Environ. Technol. 2016, 37, 3055-3061. [CrossRef]

52. Prasertsan, P.; Prasertsan, S.; H-Kittikun, A. Recycling of agro-industrial wastes through cleaner technology. Biotechnol. Encycl. Life Support Syst. 1997, 10, 1-11.

53. Poulain, A.J.; Newman, D.K. Rhodobacter capsulatus catalyzes light-dependent Fe(II) oxidation under anaerobic conditions as a potential detoxification mechanism. Appl. Environ. Microbiol. 2009, 75, 6639-6646. [CrossRef] [PubMed]

54. Pfennig, N. Rhodopseudomonas acidophila, sp. n., a new species of the budding purple nonsulfur bacteria. J. Bacteriol. 1969, 99, 597-602. [CrossRef] [PubMed]

55. Noparatnaraporn, N.; Trakulnaleumsai, S.; Silveira, R.G.; Nishizawa, Y.; Nagai, S. SCP production by mixed culture of Rhodocyclus gelatinosus and Rhodobacter sphaeroides from Cassava Waste. J. Ferment. Technol. 1987, 65, 11-16. [CrossRef]

56. Honda, R.; Fukushi, K.; Yamamoto, K. Optimization of wastewater feeding for single-cell protein production in an anaerobic wastewater treatment process utilizing purple non-sulfur bacteria in mixed culture condition. J. Biotechnol. 2006, 125, 565-573. [CrossRef]

57. Kim, J.K.; Lee, B.-K.; Kim, S.-H.; Moon, J.-H. Characterization of denitrifying photosynthetic bacteria isolated from photosynthetic sludge. Aquac. Eng. 1999, 19, 179-193. [CrossRef]

58. Kelechi, M.; Ukaegbu-Obi, K.M. Single Cell Protein: A Resort to Global Protein Challenge and Waste Management. J. Microbiol. Microb. Technol. 2016, 1, 5 .

59. Johnson, E.A. Biotechnology of non-Saccharomyces yeasts-the ascomycetes. Appl. Microbiol. Biotechnol. 2013, 97, 503-517. [CrossRef] [PubMed]

60. Ding, C. Experiments on the biodegradation of phenol wastewater by immobilized photosynthetic bacteria. Water Resour. Prot. 2008, 24, 93-95.

61. Madukasi, E.I.; Dai, X.; He, C.; Zhou, J. Potentials of phototrophic bacteria in treating pharmaceutical wastewater. Int. J. Environ. Sci. Technol. 2010, 7, 165-174. [CrossRef]

62. Chen, C.C.; Shih, Y.C.; Chiou, P.; Yu, B. Evaluating Nutritional Quality of Single Stage- and Two Stage-fermented Soybean Meal. Asian Australas. J. Anim. Sci. 2010, 23. [CrossRef]

63. Kantachote, D.; Torpee, S.; Umsakul, K. The potential use of anoxygenic phototrophic bacteria for treating latex rubber sheet wastewater. Electron. J. Biotechnol. 2005, 8, 314-323. [CrossRef]

64. Kalyuzhnaya, M.G.; Puri, A.W.; Lidstrom, M.E. Metabolic engineering in methanotrophic bacteria. Metabol. Eng. 2015, 29, 142-152. [CrossRef] [PubMed]

65. Beardall, J.; Raven, J.A. Algal Metabolism. Encycl. Life Sci. 2012. [CrossRef]

66. Falkowski, P.G.; Raven, J.A. Aquatic Photosynthesis, 2nd ed.; STU-Student Edition, Ed.; Princeton University Press: Princeton, NJ, USA, 2007.

67. Radmer, R.J.; Parker, B.C. Commercial applications of algae: Opportunities and constraints. J. Appl. Phycol. 1994, 6, 93-98. [CrossRef]

68. Darcy Vrillon, B. Nutritional aspects of the developing use of marine macroalgae for the human food industry. Int. J. Food Sci. Nutr. 1993, 44, S23-S35.

69. Wood, A.; Toerien, D.F.; Robinson, R.K. Developments in Food Proteins-7; Hudson, B.J.F., Ed.; Elsevier Applied Science: London, UK, 1991.

70. Heimann, K.; Huerlimann, R. Microalgal Classification: Major Classes and Genera of Commercial Microalgal Species. In Handbook of Marine Microalgae; Kim, S.-K., Ed.; Academic Press: Boston, MA, USA, 2015; Chapter 3; pp. $25-41$.

71. Nasseri, A.T.; Rasoul-Amini, S.; Morowvat, M.H.; Younes, G. Single Cell Protein: Production and Process. Am. J. Food Technol. 2011, 6. [CrossRef]

72. Chronakis, I.S. Biosolar proteins from aquatic algae. In Developments in Food Science; Doxastakis, G., Kiosseoglou, V., Eds.; Elsevier: Amsterdam, The Netherlands, 2000; Volume 41, pp. 39-75.

73. García-Garibay, M.; Gómez-Ruiz, L.; Cruz-Guerrero, A.E.; Bárzana, E. Single cell protein I The Algae. In Encyclopedia of Food Microbiology, 2nd ed.; Batt, C.A., Tortorello, M.L., Eds.; Academic Press: Oxford, UK, 2014; pp. 425-430.

74. Jadeja, R.N.; Tewari, A. Effect of soda ash industry effluent on protein content of two green seaweeds. J. Hazard. Mater. 2008, 151, 559-561. [CrossRef] 
75. Putri, D.; Ulhidayati, A.; Musthofa, I.A.; Wardani, A.K. Single cell protein production of Chlorella sp. using food processing waste as a cultivation medium. In IOP Conference Series: Earth and Environmental Science; IOP Publishing: Bristol, UK, 2018; Volume 131, p. 012052. [CrossRef]

76. Spalvins, K.; Zihare, L.; Blumberga, D. Single cell protein production from waste biomass: Comparison of various industrial by-products. Energy Procedia 2018, 147, 409-418. [CrossRef]

77. Gressler, V.; Yokoya, N.S.; Fujii, M.T.; Colepicolo, P.; Filho, J.M.; Torres, R.P.; Pinto, E. Lipid, fatty acid, protein, amino acid and ash contents in four Brazilian red algae species. Food Chem. 2010, 120, 585-590. [CrossRef]

78. Fleurence, J. Seaweed proteins: Biochemical, nutritional aspects and potential uses. Trends Food Sci. Technol. 1999, 10, 25-28. [CrossRef]

79. Fleurence, J.; Morançais, M.; Dumay, J.; Decottignies, P.; Turpin, V.; Munier, M.; Garcia-Bueno, N.; Jaouen, P. What are the prospects for using seaweed in human nutrition and for marine animals raised through aquaculture? Trends Food Sci. Technol. 2012, 27, 57-61. [CrossRef]

80. Galland-Irmouli, A.V.; Fleurence, J.; Lamghari, R.; Luçon, M.; Rouxel, C.; Barbaroux, O.; Bronowicki, J.P.; Villaume, C.; Guéant, J.L. Nutritional value of proteins from edible seaweed Palmaria palmata (dulse). J. Nutr. Biochem. 1999, 10, 353-359. [CrossRef]

81. Morrissey, J.; Kraan, S.; Guiry, M.D. A Guide to Commercially Important Seaweeds on the Irish Coast; Irish Bord Iascaigh Mhara/Irish Sea Fisheries Board: Dublin, Ireland, 2001.

82. Rupérez, P.; Saura-Calixto, F. Dietary fibre and physicochemical properties of edible Spanish seaweeds. Eur. Food Res. Technol. 2001, 212, 349-354. [CrossRef]

83. Nuñez, V.c.J.; Voltolina, D.; Nieves, M.; Piña, P.; Medina, A.; Guerrero, M.n. Nitrogen budget in Scenedesmus obliquus cultures with artificial wastewater. Bioresour. Technol. 2001, 78, 161-164. [CrossRef]

84. Volkmann, H.; Imianovsky, U.; Oliveira, J.; Sant'Anna, E. Cultivation of Arthrospira (spirulina) platensis in desalinator wastewater and salinated synthetic medium: Protein content and amino-acid profile Cultivo de Arthrospira (Spirulina) platensis em rejeito de dessalinizador e meio sintético salinizado: Teor protéico e perfil de aminoácidos. Braz. J. Microbiol. 2008, 39. [CrossRef]

85. Rouxel, C.; Daniel, A.; Jérôme, M.; Etienne, M.; Fleurence, J. Species identification by SDS-PAGE of red algae used as seafood or a food ingredient. Food Chem. 2001, 74, 349-353. [CrossRef]

86. Sharif, M.; Zafar, M.H.; Aqib, A.I.; Saeed, M.; Farag, M.R.; Alagawany, M. Single cell protein: Sources, mechanism of production, nutritional value and its uses in aquaculture nutrition. Aquaculture 2021, 531, 735885. [CrossRef]

87. Takahashi, J.A.; Barbosa, B.V.R.; Martins, B.d.A.; Guirlanda, C.P.; Moura, M.A.F. Use of the Versatility of Fungal Metabolism to Meet Modern Demands for Healthy Aging, Functional Foods, and Sustainability. J. Fungi 2020, 6, 223. [CrossRef]

88. Demain, A.L.; Fang, A. The Natural Functions of Secondary Metabolites. In History of Modern Biotechnology I; Fiechter, A., Ed.; Springer: Heidelberg, Germany, 2000; pp. 1-39. [CrossRef]

89. Keller, N.P.; Turner, G.; Bennett, J.W. Fungal secondary metabolism-From biochemistry to genomics. Nat. Rev. Microbiol. 2005, 3, 937-947. [CrossRef]

90. Dufossé, L.; Fouillaud, M.; Caro, Y.; Mapari, S.A.; Sutthiwong, N. Filamentous fungi are large-scale producers of pigments and colorants for the food industry. Curr. Opin. Biotechnol. 2014, 26, 56-61. [CrossRef]

91. Hoffmeister, D.; Keller, N.P. Natural products of filamentous fungi: Enzymes, genes, and their regulation. Nat. Prod. Rep. 2007, 24, 393-416. [CrossRef] [PubMed]

92. Kohlhaw, G.B. Leucine biosynthesis in fungi: Entering metabolism through the back door. Microbiol. Mol. Biol. Rev. 2003, 67, 1-15. [CrossRef] [PubMed]

93. Schardl, C.L.; Young, C.A.; Hesse, U.; Amyotte, S.G.; Andreeva, K.; Calie, P.J.; Fleetwood, D.J.; Haws, D.C.; Moore, N.; Oeser, B.; et al. Plant-Symbiotic Fungi as Chemical Engineers: Multi-Genome Analysis of the Clavicipitaceae Reveals Dynamics of Alkaloid Loci. PLoS Genet. 2013, 9, e1003323. [CrossRef] [PubMed]

94. Brakhage, A.A. Regulation of fungal secondary metabolism. Nat. Rev. Microbiol. 2013, 11, 21-32. [CrossRef]

95. Ravinder, R.; Linga, V.; Ravindra, P. Studies on Aspergillus oryzae Mutants for the Production of Single Cell Proteins from Deoiled Rice Bran. Food Technol. Biotechnol. 2003, 41, 243-246.

96. Turnbull, W.H.; Leeds, A.R.; Edwards, D.G. Mycoprotein reduces blood lipids in free-living subjects. Am. J. Clin. Nutr. 1992, 55, 415-419. [CrossRef]

97. Nangul, A.; Bhatia, R. Microorganisms: A marvelous source of single cell proteins. J. Microbiol. Biotechnol. Food Sci. 2013, 3, 15-18.

98. Valentino, M.J.; Ganado, L.; Undan, J.R. Single cell protein potential of endophytic fungi associated with bamboo using rice bran as substrate. Adv. Appl. Sci. Res. 2016, 7, 68-72.

99. Ahmadi, A.R.; Ghoorchian, H.; Hajihosaini, R.; Khanifar, J. Determination of the amount of protein and amino acids extracted from the microbial protein (SCP) of lignocellulosic wastes. Pak. J. Biol. Sci. 2010, 13, 355-361. [CrossRef] [PubMed]

100. Rodríguez, J.; Ferraz, A.; Nogueira, R.F.; Ferrer, I.; Esposito, E.; Durán, N. Lignin biodegradation by the ascomycete Chrysonilia sitophila. Appl. Biochem. Biotechnol. 1997, 62, 233-242. [CrossRef] [PubMed]

101. Bhalla, T.C.; Joshi, M. Protein enrichment of apple pomace by co-culture of cellulolytic moulds and yeasts. World J. Microbiol. Biotechnol. 1994, 10, 116-117. [CrossRef]

102. Baldensperger, J.; Le Mer, J.; Hannibal, L.; Quinto, P.J. Solid state fermentation of banana wastes. Biotechnol. Lett. 1985, 7, 743-748. [CrossRef] 
103. De Gregorio, A.; Mandalari, G.; Arena, N.; Nucita, F.; Tripodo, M.M.; Lo Curto, R.B. SCP and crude pectinase production by slurry-state fermentation of lemon pulps. Bioresour. Technol. 2002, 83, 89-94. [CrossRef]

104. Chiou, P.W.S.; Chiu, S.W.; Chen, C.R. Value of Aspergillus niger fermentation product as a dietary ingredient for broiler chickens. Anim. Feed Sci. Technol. 2001, 91, 171-182. [CrossRef]

105. Wiebe, M.G. Myco-protein from Fusarium venenatum: A well-established product for human consumption. Appl. Microbiol. Biotechnol. 2002, 58, 421-427. [CrossRef]

106. Şişman, T.; Gür, Ö.; Doğan, N.; Özdal, M.; Algur Ö, F.; Ergon, T. Single-cell protein as an alternative food for zebrafish, Danio rerio: A toxicological assessment. Toxicol. Ind. Health 2013, 29, 792-799. [CrossRef]

107. Klug, L.; Daum, G. Yeast lipid metabolism at a glance. FEMS Yeast Res. 2014, 14, 369-388. [CrossRef]

108. Sitepu, I.; Selby, T.; Lin, T.; Zhu, S.; Boundy-Mills, K. Carbon source utilization and inhibitor tolerance of 45 oleaginous yeast species. J. Ind. Microbiol. Biotechnol. 2014, 41, 1061-1070. [CrossRef]

109. Stincone, A.; Prigione, A.; Cramer, T.; Wamelink, M.M.; Campbell, K.; Cheung, E.; Olin-Sandoval, V.; Grüning, N.M.; Krüger, A.; Tauqeer Alam, M.; et al. The return of metabolism: Biochemistry and physiology of the pentose phosphate pathway. Biol. Rev. Camb. Philos. Soc. 2015, 90, 927-963. [CrossRef]

110. Kieliszek, M.; Kot, A.; Bzducha-Wróbel, A.; Błażejak, S.; Gientka, I.; Kurcz, A. Biotechnological use of Candida yeasts in the food industry: A review. Fungal Biol. Rev. 2017, 31, 185-198. [CrossRef]

111. Bennett, J.W.; Keller, N.P. Mycotoxins and their prevention. In Fungal Biotechnology; Chapman \& Hall: Weinheim, Germany, 1997; pp. 265-271.

112. Aggelopoulos, T.; Katsieris, K.; Bekatorou, A.; Pandey, A.; Banat, I.M.; Koutinas, A.A. Solid state fermentation of food waste mixtures for single cell protein, aroma volatiles and fat production. Food Chem. 2014, 145, 710-716. [CrossRef] [PubMed]

113. Yadav, J.S.; Bezawada, J.; Ajila, C.M.; Yan, S.; Tyagi, R.D.; Surampalli, R.Y. Mixed culture of Kluyveromyces marxianus and Candida krusei for single-cell protein production and organic load removal from whey. Bioresour. Technol. 2014, 164, 119-127. [CrossRef] [PubMed]

114. Gao, Y.; Li, D.; Liu, Y. Production of single cell protein from soy molasses using Candida tropicalis. Ann. Microbiol. 2012, 62, 1165-1172. [CrossRef]

115. Pessoa, A.; Mancilha, I.M.; Sato, S. Cultivation of Candida tropicalis in sugar cane hemicellulosic hydrolyzate for microbial protein production. J. Biotechnol. 1996, 51, 83-88. [CrossRef]

116. Zhao, G.; Zhang, W.; Zhang, G. Production of single cell protein using waste capsicum powder produced during capsanthin extraction. Lett. Appl. Microbiol. 2010, 50, 187-191. [CrossRef]

117. Jalasutram, V.; Kataram, S.; Gandu, B.; Anupoju, G.R. Single cell protein production from digested and undigested poultry litter by Candida utilis: Optimization of process parameters using response surface methodology. Clean Technol. Environ. Policy 2013, 15, 265-273. [CrossRef]

118. Kurcz, A.; Błażejak, S.; Kot, A.M.; Bzducha-Wróbel, A.; Kieliszek, M. Application of Industrial Wastes for the Production of Microbial Single-Cell Protein by Fodder Yeast Candida utilis. Waste Biomass Valorization 2018, 9, 57-64. [CrossRef]

119. Hashem, M.; Hesham, A.E.-L.; Alamri, S.A.; Alrumman, S.A. Production of single-cell protein from wasted date fruits by Hanseniaspora uvarum KKUY-0084 and Zygosaccharomyces rouxii KKUY-0157. Ann. Microbiol. 2014, 64, 1505-1511. [CrossRef]

120. Paraskevopoulou, A.; Athanasiadis, I.; Kanellaki, M.; Bekatorou, A.; Blekas, G.; Kiosseoglou, V. Functional properties of single cell protein produced by kefir microflora. Int. Food Res. J. 2003, 36, 431-438. [CrossRef]

121. Duarte, L.C.; Carvalheiro, F.; Lopes, S.; Neves, I.; Gírio, F.M. Yeast Biomass Production in Brewery's Spent Grains Hemicellulosic Hydrolyzate. Appl. Biochem. Biotechnol. 2008, 148, 119-129. [CrossRef] [PubMed]

122. Cui, W.; Wang, Q.; Zhang, F.; Zhang, S.-C.; Chi, Z.-M.; Madzak, C. Direct conversion of inulin into single cell protein by the engineered Yarrowia lipolytica carrying inulinase gene. Process. Biochem. 2011, 46, 1442-1448. [CrossRef]

123. Wu, G.; Fanzo, J.; Miller, D.D.; Pingali, P.; Post, M.; Steiner, J.L.; Thalacker-Mercer, A.E. Production and supply of high-quality food protein for human consumption: Sustainability, challenges, and innovations. Ann. N. Y. Acad. Sci. 2014, 1321, 1-19. [CrossRef]

124. Boland, M.J.; Rae, A.N.; Vereijken, J.M.; Meuwissen, M.P.M.; Fischer, A.R.H.; van Boekel, M.A.J.S.; Rutherfurd, S.M.; Gruppen, H.; Moughan, P.J.; Hendriks, W.H. The future supply of animal-derived protein for human consumption. Trends Food Sci. Technol. 2013, 29, 62-73. [CrossRef]

125. Linder, T. Making the case for edible microorganisms as an integral part of a more sustainable and resilient food production system. Food Secur. 2019, 11, 265-278. [CrossRef]

126. Finnigan, T.; Needham, L.; Abbott, C. Mycoprotein: A Healthy New Protein With a Low Environmental Impact. In Sustainable Protein Sources; Nadathur, S.R., Wanasundara, J.P.D., Scanlin, L., Eds.; Academic Press: San Diego, CA, USA, 2017; Chapter 19; pp. 305-325. [CrossRef]

127. Bogdahn, I. Agriculture-independent, sustainable, fail-safe and efficient food production by autotrophic single-cell protein. PeerJ PrePrints 2015, 3, e1279v1273. [CrossRef]

128. Ferreira, I.M.P.L.V.O.; Pinho, O.; Vieira, E.; Tavarela, J.G. Brewer's Saccharomyces yeast biomass: Characteristics and potential applications. Trends Food Sci. Technol. 2010, 21, 77-84. [CrossRef]

129. Yousufi, M.K. To determine protein content of single cell protein produced by using various combination of fruit wastes and two standard food fungi. Int. J. Adv. Biotechnol. Res. 2012, 3, 533-536.

130. Anupama; Ravindra, P. Value-added food:: Single cell protein. Biotechnol. Adv. 2000, 18, 459-479. [CrossRef] 
131. Zhou, Y.-M.; Chen, Y.-P.; Shen, Y. Single cell protein-feed: Taking orange waste as raw material for fermentation. In Advanced Materials and Energy Sustainability; World Scientific: Singapore, 2017; pp. 323-335. [CrossRef]

132. Aruna, T.E.; Aworh, O.C.; Raji, A.O.; Olagunju, A.I. Protein enrichment of yam peels by fermentation with Saccharomyces cerevisiae (BY4743). Ann. Agric. Sci. 2017, 62, 33-37. [CrossRef]

133. Adedayo, M.R.; Ajiboye, E.A.; Akintunde, J.K.; Odaibo, A. Single Cell Proteins: As Nutritional Enhancer. Adv. Appl. Sci. Res. 2011, 2, 396-409.

134. Bhalla, T.; Sharma, N.N.; Sharma, M. Production of Metabolites, Industrial enzymes, Amino acid, Organic acids, Antibiotics, Vitamins and Single Cell Proteins. J. Environ. 2007, 6, 34-78.

135. Jamal, P.; Alam, M.; Salleh, N. Medai optimization for bioproteins productions from cheaper carbon source. J. Eng. Sci. Technol. 2008, 3, 124-130.

136. Mahajan, A.; Dua, S. A perspective on biotechnological potential. J. Food Sci. Technol. 1995, 32, $162-165$.

137. McEvoy, L.A.; Navarro, J.C.; Hontoria, F.; Amat, F.; Sargent, J.R. Two novel Anemia enrichment diets containing polar lipid. Aquaculture 1996, 144, 339-352. [CrossRef]

138. Olvera-Novoa, M.A.; MartÍNez-Palacios, C.A.; Olivera-Castillo, L. Utilization of torula yeast (Candida utilis) as a protein source in diets for tilapia (Oreochromis mossambicus Peters) fry. Aquac. Nutr. 2002, 8, 257-264. [CrossRef]

139. Hardy, R.W.; Patro, B.; Pujol-Baxley, C.; Marx, C.J.; Feinberg, L. Partial replacement of soybean meal with Methylobacterium extorquens single-cell protein in feeds for rainbow trout (Oncorhynchus mykiss Walbaum). Aquac. Res. 2018, 49, $2218-2224$. [CrossRef]

140. Oliva-Teles, A.; Gonçalves, P. Partial replacement of fishmeal by brewers yeast (Saccaromyces cerevisae) in diets for sea bass (Dicentrarchus labrax) juveniles. Aquaculture 2001, 202, 269-278. [CrossRef]

141. Tovar, D.; Zambonino, J.; Cahu, C.; Gatesoupe, F.J.; Vázquez-Juárez, R.; Lésel, R. Effect of live yeast incorporation in compound diet on digestive enzyme activity in sea bass (Dicentrarchus labrax) larvae. Aquaculture 2002, 204, 113-123. [CrossRef]

142. Tesfaw, A.; Assefa, F. Co-culture: A great promising method in single cell protein production. Biotechnol. Mol. Biol. Rev. 2014, 9 , 12-20. [CrossRef]

143. Protein Extracts from Single Cell Protein and Other Conventional Sources Market Analysis By Sources (Plant, Bacteria, Yeast, Algae, Fungi), By Applications (Pharma, Animal Feed \{Isolate, Concentrate, Hydrolysate\}, Agriculture), And Segment Forecasts, 2018-2025. Available online: https:/ / www.grandviewresearch.com/industry-analysis/protein-extracts-from-single-cell-proteinother-conventional-sources-market (accessed on 25 June 2021). 